\title{
Bożena Lesiak-Przybył*
}

\section{Wielka wojna w „Dzienniku” Aleksandry Czechówny (część V: 5 stycznia - 2 listopada 1918 r.) ${ }^{1}$}

Oddajemy Czytelnikom piątą część edycji „Dziennika” Aleksandry Czechówny opisującej lata I wojny światowej². Obejmuje ona okres od 5 stycznia do 2 listopada 1918 r. Szerzej o autorce i okolicznościach rozpoczęcia

* starszy kustosz, Archiwum Narodowe w Krakowie; zainteresowania badawcze: dzieje i ikonografia Krakowa w XIX i XX w., edytorstwo źródeł, biografistyka, popularyzacja zbiorów i muzealnictwo; e-mail: blesiak@ank.gov.pl

${ }^{1} \mathrm{~W}$ okresie międzywojennym świętem państwowym upamiętniającym rocznicę wskrzeszenia niepodległej Polski był dzień 11 listopada, kiedy rozpoczęło się rozbrajanie żołnierzy niemieckich w Warszawie i w północnej części Królestwa Polskiego, a Rada Regencyjna przekazała Józefowi Piłsudskiemu władzę wojskową i naczelne dowództwo nad Wojskiem Polskim. Sam Piłsudski skłonny był datę formalnego odzyskania niepodległości przesunąć na dzień 22 listopada - kiedy to rząd Jędrzeja Moraczewskiego (1870-1944) wydał dekret o najwyższej władzy reprezentacyjnej Republiki Polskiej, który czynił Piłsudskiego tymczasowym naczelnikiem państwa (aż do czasu zwołania sejmu ustawodawczego). Niektórzy za taką datę skłonni są uznawać noc z 6 na 7 listopada, kiedy to w Lublinie ukonstytuował się Tymczasowy Rząd Ludowy Republiki Polskiej z Ignacym Daszyńskim na czele i ogłosił radykalny „Manifest do Ludu Polskiego”. Kraków natomiast został wyzwolony już 31 października 1918 r. Ponieważ autorka „Dziennika” mieszkała w Krakowie, dlatego Z wydarzeniami tego dnia kończymy tę relację, zob. też Marian Zgórniak, 1914-1918. Studia i szkice z dziejów I wojny światowej, Kraków 1987, s. 255-256.

${ }^{2}$ Oryginał „Dziennika” Aleksandry Czechówny przechowywany jest w zbiorach Archiwum Narodowego w Krakowie, Spuścizna Aleksandry Czechówny, sygn. 29/1582 (dawna sygn. IT 428). Część I wspomnianej edycji zob. Bożena Lesiak-Przybył, Wielka wojna w „Dzienniku” Aleksandry Czechówny (część I: 2 lipca 1914 r. - 26 grudnia 1914 r.), „Krakowski Rocznik Archiwalny” 2014, t. 20, s. 111-132; część II zob. eade m, Wielka wojna w „Dzienniku” Aleksandry Czechówny (czesść II: 2 stycznia - 26 grudnia 1915 r.), „Krakowski Rocznik Archiwalny” 2015, t. 21, s. 133-163; część III zob. eadem, Wielka wojna w „Dzienniku” Aleksandry Czechówny (część III: 2 stycznia - 27 grudnia 1916 r.), „Krakowski Rocznik Archiwalny” 2016, t. 22, s. 139-170; część IV zob. eadem, Wielka wojna w „Dzienniku” Aleksandry Czechówny (część IV: 1 stycznia - 29 grudnia 1917 r.), „Krakowski Rocznik Archiwalny” 2017, t. 23, s. 181-215. 
i wieloletniego kontynuowania przez nią „Dziennika” pisaliśmy we Wstępie do I części edycji ${ }^{3}$. Tu wypada dodać tylko kilka uwag.

Kolejny, 1918 r., ostatni rok wojny, rozpoczął się dla Polaków, wydawać by się mogło optymistycznie, od orędzia prezydenta Stanów Zjednoczonych Thomasa Woodrow Wilsona, w którym w punkcie 13. wysunięto postulat odbudowy niepodległego państwa polskiego obejmującego zamieszkałe przez ludność polską ziemie z dostępem do morza. Postawienie takiego warunku wywołało radosne poruszenie wśród Polaków.

Sam Kraków pozostawał w tym czasie daleko poza linią frontu i nie był zagrożony bezpośrednimi działaniami wojennymi. Jednak mieszkańcy miasta byli coraz bardziej wyczerpani i przygnębieni przedłużającymi się trudnościami dnia codziennego. Już jesienią 1917 r. sytuacja ludności była katastrofalna. Tymczasem nowy rok rozpoczął się ponownym zmniejszeniem racji chleba i mąki o $25 \%{ }^{4}$, i nadal rosnącą drożyzną. Brak podstawowych artykułów spożywczych, szalejące ceny przyczyniały się do coraz większej biedy wśród mieszkańców. W styczniu kolejny raz doszło do rozruchów ulicznych. Policja rozpędziła demonstrację głodową na Kazimierzu, lecz zaraz następnego dnia thuczono okna i niszczono sklepy spożywcze przy ulicy Długiej. W połowie stycznia A. Czechówna napisała:

...Z powodu braku chleba i w ogóle najsmutniejszej aprowizacji, która do rozpaczy doprowadza biedniejszą ludność, zaczynają się i w Krakowie rozruchy, i gdy tylko się ściemni, liczne bandy napadają na sklepy, zabierają co się da, wybijają szyby, czynią wielkie szkody, a właściwie bez żadnego dobrego skutku, cóż bowiem winni im kupcy, że chleba nie mają.

Rezultat zaś tych rozruchów jest ten, że coraz trudniej jest coś dostać, gdyż wszystkie sklepy są ze zmierzchem pozamykane, i nie wiem tylko, co słychać z kawiarniami, i czy tam nie napadają.

Rozruchy te mogą jednak mieć tę dobrą stronę, iż zwrócą uwagę wyższych władz na to, że nasza Galicja jest tak po macoszemu traktowana i wprost ogładzana [!], gdy wszystkie nasze produkta i węgle są masowo wywożone do Prus albo do Wiednia i następstwem tego jest u nas taka bieda i po prostu głód ${ }^{5}$.

${ }^{3}$ Szerzej o Aleksandrze Czechównie i odnośnej literaturze źródłowej zob. B. Lesiak-Przybył, Wielka wojna w „Dzienniku” Aleksandry Czechówny (część I...), s. 111-115.

${ }^{4}$ W „Czasie” nr 8 z 5 stycznia 1918 r., s. 2 Magistrat poinformował mieszkańców Krakowa o obowiązującym od 6 stycznia do odwołania ograniczeniu racji chleba i mąki o $25 \%$.

${ }^{5}$ Cytaty we Wstępie pochodzą z zamieszczonej poniżej edycji „Dziennika”. 
Nadal uważano, że żywność dostarczana jest w pierwszym rzędzie do innych miast Austrii i Prus, a Kraków w tym względzie jest dyskryminowany. W związku z trwającymi rozruchami ukazały się rozporządzenia o zamykaniu kawiarni o godzinie 16, a po 18 wolno było wychodzić z domów tylko w ważnych sprawach.

W sferze polityki też zachodziły przełomowe zmiany, co pamiętnikarka podsumowała:

...żyjemy wśród takiego zamętu i nieprzewidzianych niespodzianek, iż zdaje mi się, że i najgłębszy polityk nie może się w tym chaosie zorientować, a tem mniej nie może przewidzieć, co się jeszcze z tego chaosu wyłoni.

Nastroje antyniemieckie szerzyły się od dawna, teraz i antyaustriackie były coraz powszechniejsze. Chyba nikt nie popierał już postulatu, by powołać Habsburga na tron polski. Do pełnego zdyskredytowania monarchii austro-węgierskiej w oczach Polaków przyczynił się podpisany 9 lutego traktat w Brześciu oddający Ukraińcom Chełmszczyznę. Jako wyraz niezadowolenia, od 11 lutego przez kolejnych kilka dni, trwały w Krakowie burzliwe demonstracje i rozruchy:

...Niemcy i Austria zawarły pokój z Ukrainą, odstępując im naszą ziemię chełmską i Podlasie. Ponieważ stało się to po owych szumnych obietnicach Austrio-Niemiec, oburzenie więc wśród ludności polskiej jest powszechne. Wywołuje to wprost rewolucyjne objawy. Dom, gdzie był jakiś urząd pruski, zdemolowano, poturbowawszy urzędników, po ulicach przechodzą liczne pochody śpiewające albo nasze pieśni patriotyczne, albo krzyczące „hańba Niemcom”, biada zaś niemieckiemu wojskowemu, bo gdy tylko jego zachowanie nie spodoba się w czemkolwiek tłumowi, rzucają się na niego, łamią pałasze i czasem i poranią. Pozdzierali także wszędzie orły austriackie, portrety

${ }^{6}$ W dniu 9 lutego 1918 r. Niemcy i Austro-Węgry w Brześciu Litewskim zawarły traktat pokojowy z delegacją Centralnej Rady Ukraińskiej (Ukraińska Republika Ludowa). Polacy nie zostali dopuszczeni do rokowań. Uznano istnienie Ukrainy i przyznano jej całą Chełmszczyznę, a także przyrzeczono wyodrębnienie Galicji Wschodniej jako osobnego kraju koronnego Austro-Węgier. Ukraina miała dostarczyć Państwom Centralnym m.in. ok. miliona ton zboża oraz do 50 tysięcy ton żywca. Traktat pokojowy Państw Centralnych z Rosją Sowiecką został zawarty 3 marca 1918 r. Jeden z jego artykułów zobowiązywał Rosję do natychmiastowego zawarcia pokoju z Ukrainą i do uznania postanowień traktatu z 9 lutego. 
cesarza Karola ${ }^{7}$ popalono w szkołach wobec profesorów, jednem słowem oburzenie powszechne ${ }^{8}$.

Na poniedziałek zapowiedziane są jeszcze większe demonstracje, mowy na Rynku i pochód na Wawel. Oby to tylko nie pociągło nowych ofiar w ludziach, gdyż wszyscy są tak oburzeni tem wiarołomstwem Austrii i jej służalstwem względem Prus, że w jednym dniu Austria straciła całą naszą sympatię. Przekonaliśmy się, że na jej obietnice nic rachować nie można, a cesarz Karol, o którym tak wiele mówiono, jako o przyszłym królu polskim, okazał się tak nikczemną i przewrotną kreaturą, że dziś już żaden Polak zamiaru tego mieć już pewnie nie będzie.

I rzeczywiście, w dniu 18 lutego doszło do wielkiej narodowej demonstracji i strajku powszechnego. Stanęły koleje, urzędy, zakłady pracy, zamknięto sklepy. A. Czechówna uznała, że w tak ważnej chwili i ona musi być obecna na Rynku krakowskim. Mimo jej wcześniejszych obaw, by nie doszło do zamieszek

...Wszystko odbyło się poważnie, majestatycznie, a jednak wśród tej całej uroczystości zbierało się na płacz. - Gdy bowiem wszystkie nasze nadzieje zostały tak haniebnie zawiedzionemi i gdy się przekonujemy, że o tyle tylko nam Polakom schlebiają, o ile nas potrzebują, a gdzie mogą to krzywdzą, serce kraje się z boleści...

${ }^{7}$ Karol I Habsburg (1887-1922), od 21 listopada 1916 r. cesarz Austro-Węgier (od 30 listopada 1916 r. król Węgier). Po objęciu władzy podejmował szereg inicjatyw dyplomatycznych zmierzających do zakończenia wojny oraz ocalenia monarchii (poprzez przekształcenie jej w federację autonomicznych krajów narodowych). Wszystkie negatywnie przyjęte zarówno przez państwa Ententy, jak i Niemcy. 16 października 1918 r. cesarz wydał manifest, w którym zapowiedział przekształcenie monarchii w państwo związkowe. Był to jednak krok spóźniony. Wobec zaistniałej sytuacji (również w kraju) 11 listopada 1918 r. ogłosił, że nie abdykuje, ale rezygnuje z udziału w rządach. Pięć miesięcy później wraz z rodziną udał się do Szwajcarii. Stamtąd w 1921 r. podjął dwie nieudane próby odzyskania tronu węgierskiego, jednak zdrada i sprzeciw państw ościennych uniemożliwiły mu powrót do władzy. W listopadzie wraz z rodziną został wywieziony na Maderę. Fatalne warunki życia przyczyniły się do jego śmierci. Karol I został beatyfikowany 3 października 2004 r. przez papieża Jana Pawła II.

${ }^{8} 11$ lutego rozpoczęły się w Krakowie, trwające kilka dni, burzliwe demonstracje antyniemieckie i antyaustriackie. Dla stłumienia ich władze sprowadziły z Wiednia, uchodzące za najwierniejsze monarchii, pułki tyrolskie. Wzmocniono garnizony w Krakowie i w innych miastach Galicji. Natomiast władze miasta Krakowa w dniu 12 lutego 1918 r. wezwały obywateli i młodzież do zachowania spokoju i równocześnie zapowiedziały przygotowanie przez Komitet złożony z przedstawicieli wszystkich stronnictw zorganizowanego protestu przeciwko decyzjom podjętym w Brześciu Litewskim, ANK, Zbiór afiszy i plakatów, sygn. 29/665/1195, 29/665/1475. 
Pamiętnikarka zapisała też rotę złożonej wówczas przysięgi, w której obecni ślubowali dążenie do odzyskania „zjednoczonej - niepodległej - nieuszczuplonej Polski"’.

W Krakowie przez kilka kolejnych miesięcy życie codzienne, można by sądzić, toczyło się normalnie. Niewiele mówiono o działaniach wojennych, głównym tematem były stale rosnące ceny artykułów spożywczych czy brak węgla. Sytuacja aprowizacyjna i materialna mieszkańców pogarszała się gwałtownie. Pieniądze coraz bardziej się dewaluowały. Pogarszające się warunki życia codziennego odczuwali już nie tylko robotnicy i ludność uboższa, lecz także lepiej sytuowana inteligencja. Władze usiłowały wprawdzie temu zapobiec środkami administracyjnymi - wyznaczając ceny maksymalne i nakładając surowe kary na spekulantów, ale na niewiele się to zdało. Nikt nie stosował się do urzędowej taryfy cen, wszyscy sprzedający żądali znacznie wyższych kwot. Źle odżywiający się ludzie byli coraz mniej odporni i często chorowali. We wrześniu i początkach października dotarła do Krakowa i okolicznych miejscowości epidemia ostrej grypy zwanej ,hiszpanką", która spowodowała liczne ofiary śmiertelne.

W czerwcu Czechówna, zaproszona przez siostrzenicę Julię, podobnie jak rok wcześniej, zdecydowała się wyjechać do Świdnika ${ }^{10}$, by odetchnąć i oderwać się od trudnego życia w wojennym Krakowie. Pobyt na wsi pomógł pamiętnikarce wzmocnić się i odpocząć. Ale i tam martwiła się, gdyż w drugiej połowie sierpnia napisała:

...Nie dość, że wojna nas gnębi, ale i sama przyroda zdaje się znęcać nad nami. - Blisko od dwóch tygodni ciągle prawie leje. Wszystkie górskie rzeczki wezbrały, popsuły drogi [...]. Ale to jest jeszcze niczem wobec strat materialnych. - Całe łany zboża niedawno pożętego woda albo zabrała, a jeżeli jest w kopach, to te kopy rosną, że aż się zielenią [...].

Coraz większe klęski! Wszystkie rzeki w Galicji wylały, a tu cięgle nie ma pogody i żaden dzień nie przechodzi bez ulewnego deszczu. Przy tem zimno jak w jesieni, a w duszy smutek i rozpacz, widząc jak wszystkie plony w polu marnieją. [...].

Pobyt w Świdniku niespodziewanie przedłużył się aż do połowy października. Dzięki temu problemy aprowizacyjne i braki żywnościowe nie doku-

${ }^{9} \mathrm{O}$ atmosferze panującej w Krakowie po podpisaniu traktatu w Brześciu zob. też Klemens Bąkowski, Kronika Krakowa z lat 1918-1923, Kraków 1925, s. 2-4.

${ }^{10}$ Julia z Dzianottów Walterowa (1874-1933) była córką Izabeli z Czechów (18421877), siostry Aleksandry i Ludwika (Ludwina) Dzianotta (ok. 1836-1894). W 1898 r. poślubiła Władysława Waltera (1872-1916), właściciela Świdnika, wsi położonej w powiecie limanowskim, w gminie Łukowica. 
czały tak A. Czechównie. Powrót do Krakowa, zbiegł się z ważnymi dla Polski wydarzeniami, dlatego też coraz częściej na kartach „Dziennika” zaczęły pojawiać się nowe, coraz lepsze wiadomości.

Lato i jesień 1918 r. przyniosły armiom państw centralnych niepowodzenia i klęski ${ }^{11}$. Poszczególne narodowości Austro-Węgier domagały się prawa do samostanowienia. Po załamaniu się frontu bałkańskiego Niemcy i Austria wyraźnie widziały, że wojnę trzeba zakończyć. W dniu 4 października rządy tych państw zwróciły się do prezydenta Thomasa Woodrowa Wilsona z prośbą o zawieszenie broni. A. Czechówna 18 października zapisała:

...Pogrom Niemców zupełny i Rada Regencyjna w Warszawie, idąc zapewnie za wskazówkami Francji, Anglii, a przede wszystkiem Wilsona, prezydenta Stanów Amerykańskich, ogłasza Polskę niepodległą w dawnych granicach, a tem samem z Poznańskiem, Galicją, Księstwem Cieszyńskiem i z Gdańskiem jako portem. // - Niemcy są wściekli, ale zdaje się, że tym razem będą musieli ustąpić jako pobici. - Naturalnie, że radość wszędzie panuje wielka, ale zanim się to wszystko stanie, upłynie jeszcze wiele wody, a podobno i krwi, gdyż ani można przypuścić, aby wszystko gładko poszło.

[I dalej - B. L.-P.] - ...To jest tylko rzeczą pewną, że zarówno Prusy, jak i Austria są zupełnie pokonane - bezsilne i muszą, rade nie rade przyjmować warunki Wilsona, a te warunki są i ciężkie, i upokarzające ${ }^{12}$.

Wypadki toczyły się teraz coraz szybciej, każdy dzień przynosił nowe, dobre wiadomości. W Krakowie w końcu października działała już Polska Komisja Likwidacyjna ${ }^{13}$ oraz tajna organizacja posiadająca członków wśród korpusu oficerskiego wojsk austro-węgierskich. Wczesnym rankiem 31 października 1918 r. żołnierze Polacy pod dowództwem porucznika Antoniego Stawarza ${ }^{14}$ zajęli koszary austriackie w Podgórzu i rozbroili ich

${ }^{11} 29$ września 1918 r. Bułgaria, a 30 października Turcja, zawarły rozejm z państwami Koalicji.

125 października książę Maksymilian w imieniu rządu Niemiec zwrócił się do prezydenta T. Wilsona z prośbą o natychmiastowe zawarcie rozejmu. Wilson rozpoczął z księciem wymianę not (tzw. „wojna na noty”). Nota trzecia z 23 października zapowiadała takie warunki rozejmu, które uniemożliwiłyby Niemcom wznowienie działań wojennych.

${ }^{13}$ W dniu 27 października w sali Rady Miejskiej w Krakowie zebrali się posłowie polscy do parlamentu austriackiego i utworzyli Polską Komisję Likwidacyjną w celu przejęcia od Austriaków władzy cywilnej na terenie autonomicznej Galicji.

${ }^{14}$ Antoni Stawarz (1889-1955), porucznik rezerwy, dowódca plutonu karabinów maszynowych w 57 Pułku Piechoty. Do sierpnia 1918 r. przebywał na Śląsku Cieszyńskim. W dniu 1 września został przeniesiony do Krakowa i otrzymał dowództwo kompanii karabinów maszynowych stacjonującej w koszarach w Podgórzu. A Stawarz rozpoczął akcję 
załogę $^{15}$. Następnie por. A. Stawarz uformował dwa oddziały żołnierzy, którzy przypiąwszy orzełki i kokardy o polskich barwach narodowych, kolejno wyruszyli w kierunku Krakowa. Oddziały te wraz z coraz liczniejszą grupą cywili przemaszerowały ulicami Podgórza i Krakowa, śpiewając pieśni patriotyczne i rozbrajając napotkanych żołnierzy austriackich. Krótko po godzinie 10 porucznik Stawarz uformował kolejny oddział pod dowództwem podporucznika Wilhelma Steca i podporucznika Jana Gawrona ${ }^{16}$ i wysłał z rozkazem zajęcia głównej strażnicy przy Wieży Ratuszowej. O godzinie 11.25 komendant warty złożonej z 15 piechurów bez oporu przekazał służbę oddziałowi polskiemu. Przy wiwatach tłumu na odwachu wywieszono polskie sztandary. Akt ten miał znaczenie symboliczne ${ }^{17}$.

W międzyczasie, niewiele po godzinie 9, austriackie dowództwo wojskowe ${ }^{18}$ udało się do magistratu, aby przeprowadzić rozmowy z przedstawicielami Polskiej Komisji Likwidacyjnej. Początkowo oficerowie austriaccy próbowali protestować, ostatecznie, pod presją demonstrujących tłumów i oddziałów wojskowych opanowujących coraz to nowe punkty, oddali władzę w mieście i twierdzy w ręce podpułkownika legionowego Bolesława Roi ${ }^{19}$, mianowanego przez Komisję Likwidacyjną komendantem wojska

o godzinie 4.30 rano, zob. Adam Chmiel, Oswobodzenie Krakowa 31 października 1918 roku, relacja por. Antoniego Stawarza, Kraków 1929, s. 30-34.

${ }^{15}$ Dziś w miejscu gdzie znajdowały się koszary, wznosi się budynek KS „Korona” (przy ul. Kalwaryjskiej). Obecni wówczas w koszarach Czesi i Ślązacy wsparli Polaków, natomiast ok. 400 żołnierzy (Niemców i Węgrów) internowano.

${ }^{16}$ Ppor. Wilhelm Stec (poległ 1 lipca 1920 r. podczas walk polsko-bolszewickich) i ppor. Jan Gawron (ur. 1895). Obydwaj awansowani przez gen. B. Roję do stopnia porucznika. Podczas marszu w kierunku Rynku dołączył do nich por. Czesław Zajączkowski.

17 A. Chmiel, Oswobodzenie Krakowa..., relacje por. A. Stawarza, por. Ludwika Iwaszki, ppor. J. Gawrona i in., s. 29-39, 50-56.

${ }^{18}$ Najwyższą władzą wojskową austriacką w Krakowie była komenda wojskowa (Militär-Kommando) kierowana przez gen. (Feldzeugmeister) Sigismunda hr. von Benigniego (1855-1922). Drugą pod względem hierarchii była komenda miasta (w miejsce zniesionej w 1917 r. komendy twierdzy), na czele której stał gen. dywizji (Feldmarschalleutnant) Mieczysław Zieliński, w tym czasie zastępowany przez gen. mjr. Viktora von Pasta (18581924). I trzecią - komenda placu (Platzkommando) pod dowództwem płk. Prokopa. W obradach uczestniczyli: gen. S. hr. von Benigni, szef sztabu generalnego płk Ludwik Grimm von Szepes-Etelvàr, generalny intendent Zaretzky, ppłk Ludwik Morawski (1868-1920) i dwóch innych wojskowych.

${ }^{19}$ Bolesław Jerzy Roja (1876-1940) ukończył szkołę kadetów w Wiedniu (1895-1898), następnie służył w 36 Pułku Obrony Krajowej w Kołomyi. W 1905 r. ze względu na stan zdrowia przeszedł do rezerwy. Od 1906 r. był agentem wywiadu austro-węgierskiego. 
polskiego. 31 października o godzinie 14.00 wszystkie ważniejsze obiekty Krakowa były już w rękach polskich ${ }^{20}$. W dniu 1 listopada 1918 r. A. Czechówna napisała:

...Wypadki postępują z taką szybkością, iż trudno nadążyć w zapisywaniu tychże. Wczoraj np. był bardzo ważny i prawdziwie historyczny dzień dla Krakowa. - Bez żadnej rewolucji i zamięszania [!], pozrzucano Orły austriackie, a umieszczono polskie. Z odwachu ustąpiła dobrowolnie załoga austriacka, a objęło takowy wojsko polskie, nad którym w Krakowie objął komendę brygadier Roja.

Sama z powodu bólu nogi w obchodach i manifestacjach nie uczestniczyła, jednak żywo interesowała się sytuacją w mieście i dzięki informacjom od przyjaciół i znajomych była na bieżąco ${ }^{21}$. Martwiły ją wiadomości o walkach, które wybuchły w Galicji Wschodniej, gdzie Ukraińcy dokonali zamachu na Lwów.

Władza wojskowa na terenie całej okupacji austro-węgierskiej przestała istnieć, znalazła się w rękach polskich. Rada Regencyjna nie była jednak w stanie jej utrzymać, zwłaszcza że nastroje społeczeństwa uległy szybkiej radykalizacji. Szerzyły się niepokoje społeczne i wystąpienia chłopów, również w byłej Galicji. Socjaliści, ludowcy i radykalny odłam inteligencji postanowili utworzyć w nocy z 6 na 7 listopada w Lublinie nowy lewicowy rząd -Tymczasowy Rząd Republiki Polskiej na czele z Ignacym Daszyńskim jako premierem i ministrem spraw zagranicznych ${ }^{22}$. Rządowi temu

Pracował jako urzędnik w Krakowie, a także studiował prawo (1908-1910) i medycynę (1910-1912) na UJ. Po wybuchu I wojny światowej wstąpił do Legionów Polskich (29 września 1914 r. otrzymał awans na kapitana). Kolejno awansował na podpułkownika (14 marca 1915 r.), pułkownika (25 września 1915 r.). Wchodził w skład Rady Pułkowników, utworzonej w maju 1916 r. Z dniem 18 czerwca 1917 r. objął dowództwo III Brygady Legionów. Po kryzysie przysięgowym 3 sierpnia 1917 r. odszedł z Legionów i przeszedł do armii austriackiej. Jesienią 1918 r. wydostał się z Grazu, gdzie był internowany i powrócił do Krakowa. W dniu 31 października 1918 r. po usunięciu komend armii austriackiej w Krakowie został mianowany przez Polską Komisję Likwidacyjną komendantem wojsk okręgu krakowskiego. Rada Regencyjna 1 listopada 1918 r. nadała mu stopień generała podporucznika.

${ }^{20}$ A. Chmiel, Oswobodzenie Krakowa..., relacje hr. Zygmunta Lasockiego, Edwarda Kubalskiego, radcy Magistratu i in., s. 39-50.

${ }^{21}$ Podobnie Maria z Kisielnickich Kossakowa (1861-1943), żona Wojciecha (18561942) z radością pisze o oswobodzeniu Polski, zob. Magdalena Samozwaniec, Maria i Magdalena, Warszawa 2010, s. 234-235.

${ }^{22}$ Ignacy Daszyński (1866-1936), działacz socjalistyczny, polityk, publicysta. W Krakowie od 1877 r. Za działalność agitacyjną wydalony ze studiów na Wydziale Filozoficz- 
nie udzieliła jednak poparcia Polska Komisja Likwidacyjna w Krakowie, która podporządkowała się formalnie dopiero utworzonemu 18 listopada w Warszawie rządowi Jędrzeja Moraczewskiego. A. Czechówna miała świadomość tych tarć i wynikających z tego problemów, bowiem napisała:

...Dziwna to doprawdy epoka, w jakiej żyjemy. Z jednej strony szczęście i spełnienie wszystkich naszych marzeń, ale z drugiej - teraźniejszość pełna grozy i obaw.

Najsmutniejsze jest to, że nie ma między nami Polakami jedności. Różne partie ścierają się między sobą i nienawidzą tak jak największych nieprzyjaciół. Wszyscy chcą rządzić, a nikt słuchać, a jako najgłośniejsze hasło rozlega się, że „Polska musi być ludową i socjalistyczną, innej nie chcemy" ${ }^{23}$.

Urzeczywistniły się marzenia Polaków, państwowość polska została przywrócona, ale zarówno sytuacja międzynarodowa, jak i wewnętrzne konflikty nadal wielu niepokoiły.

Podobnie jak w latach poprzednich pamiętnikarka wiele czytała. Zamiłowanie do literatury, widoczne na kartach całego „Dziennika”, również teraz pomagało jej przetrwać trudne chwile. Od lat uważając Fryderyka Schillera za literackiego przyjaciela i mając w pamięci słowa Lucjana Rydla, że „on najwięcej odpowiada twojej duszy”, na wakacyjny wyjazd wzięła jego dramaty historyczne: Die beiden Piccolomini, Wallensteins Tod, Dziewice Orleańska, Marię Stuart, Die Braut von Messina i Wilhelma Tella. Wielokrotnie też sięgała do Żywotów Świętych Piotra Skargi, podarowanych jej przez L. Rydla na imieniny. Przeczytała tym razem ostatni już tom Podróży do Włoch Józefa Kremera. Kontynuowała lekturę Poezji L. Rydla, a także przeczytała jego Bodenheim, dotychczas znany jej tylko ze sceny teatralnej. Przestudiowała kilka powieści należących już do klasyki literatury polskiej: Elizy Orzeszkowej Wesoła teorię $i$ smutna praktykę, Józefa Ignacego Kraszewskiego Hrabinę Cosel i Brühla, Zofii Kowerskiej Na stużbie oraz również wydaną w 1912 r., uznawaną za wybitne dzieło, powieść Józefa Weyssenhoffa Soból i panna. Z przyjemnością i zainteresowaniem zapozna-

nym UJ. Współorganizator ruchu socjalistycznego w Galicji, m.in. założyciel i przywódca Polskiej Partii Socjalno-Demokratycznej Galicji i Śląska Cieszyńskiego (1892), redaktor i wydawca „Naprzodu” (1893-1919). W latach 1897-1918 poseł do austriackiej Rady Państwa - propagator demokratyzacji stosunków galicyjskich i zwolennik odbudowy państwowości polskiej przy pomocy Austro-Węgier. W latach 1902-1919 radny $\mathrm{m}$. Krakowa.

${ }^{23}$ ANK, Spuścizna Aleksandry Czechówny, sygn. 29/1582/42 (dawna sygn. IT 428/42), s. 231. 
ła się ponadto z powieściami Eve victorieuse i Noblesse américaine, których autorka Jeanne Philomène Laperche (1853-1927) publikowała pod pseudonimem Pierre de Coulevain. Nadal czytała „Czas” i „Nową Reformę” oraz tygodnik „Nowości Illustrowane”, i z tych właśnie gazet czerpała większość informacji o tym, co dzieje się w Krakowie i na świecie. Ilustracje i wycinki z „Nowości Illustrowanych” i „Nowej Reformy” dodatkowo zamieściła na końcu zeszytu jako uzupełnienie swych relacji ${ }^{24}$.

Podobnie jak w roku poprzednim nadal chętnie chodziła na prowadzone przez L. Rydla wykłady poświęcone historii literatury oraz historii kultury i cywilizacji. Uważała, że są niezwykle ciekawe i pouczające:

...Jest to doprawdy rzecz szczególna, że kiedy wśród tej wojny odeszła mnie zupełnie ochota chodzenia do teatru, a i na koncert trudno mi się wybrać, zwłaszcza że sala Starego Teatru jest zajęta na szpital, a koncerta odbywają się w dalekim Sokole, jedne wykłady Lucjana mają zawsze równy dla mnie powab i zawsze bardzo mnie zajmują.

Przebywając w Krakowie, L. Rydel mieszkał u niej i wówczas prowadzili zajmujące rozmowy. Darzyła poetę wielką sympatią i dlatego niewątpliwie wielkim ciosem dla pamiętnikarki była jego śmierć (8 kwietnia). Już wcześniej martwiła się stanem jego zdrowia, i mało oszczędnym trybem życia. Gdy zmarł, poczuła się osamotniona i niepotrzebna. Skończyły się dyskusje literackie, rozmowy towarzyskie, przyjacielska serdeczność i żarciki. Pozostał żal, że L. Rydlowi, który marzył o wolnej i niepodległej Polsce, nie było dane doczekanie ,tej chwili, która spełnia wszystkie jego marzenia".

Prezentowany wybór zapisów z 1918 r., spisany przez wnikliwą obserwatorkę i wielką patriotkę, niewątpliwie niepełny, zwłaszcza w odniesieniu do sfery polityki, dostarcza jednak szeregu informacji o obawach i niepokojach Polaków, zarówno tych związanych z działaniami wojennymi, ale także z niezwykle już trudnym życiem codziennym mieszkańców Krakowa. Przynosi opis stanu uczuć Polaków, ich żalu, niepokoju, gotowości do walki i ostatecznie wielkiej radości z odzyskania upragnionej niepodległości.

${ }^{24} \mathrm{~W}$ tomie 42 znajdują się m.in. wycinki prasowe zawierające relacje i teksty przemówień z pogrzebu Lucjana Rydla („Nowa Reforma” nr 162 z 10 kwietnia 1918 r., s. 2; nr 164 z 11 kwietnia 1918 r., s. 2). 
Zamieszczony poniżej tekst pochodzi z 42 tomu „Dziennika”25. Opracowując tekst „Dziennika”, zachowano cechy języka, modernizując jedynie pisownię (w tym nazw geograficznych oraz nazwisk, np. Rossja, Sziller) i interpunkcję. Pozostawiono jednak charakterystyczną dla owego czasu pisownię kilku wyrazów, odmienną od współczesnej (np. zapewnie, obudzać, jenerał, jaśno, narość, gienialny, właśne, ślizgo, ogładzane, zamięszanie). Poprawiono ewidentne błędy ortograficzne (np. wziąść, w obec, dla tego, jestto, biórko, szczelba, to też). Paginację rękopisu umieszczono w nawiasach kwadratowych [ ], końce stron tekstu oryginalnego zaznaczono dwiema ukośnymi kreskami. Dla poprawy czytelności „Dziennika” ujednolicono i uzupełniono datowania dokonywanych zapisów.

Objaśnienia dotyczące osób i miejsc występujących w tekście źródłowym oraz opisywanych wydarzeń podano w przypisach rzeczowych. Dodatkowe niezbędne uzupełnienia tekstu wpisano w nawiasach kwadratowych [ ]. Czechówna miała zwyczaj umieszczać w „Dzienniku” obszerne komentarze do przeczytanych książek, wśród których ginęły informacje o tematyce wojennej, dlatego zdecydowano się większą ich część opuścić, zaznaczając to w tekście nawiasem kwadratowym i krótko streszczając w przypisie.

\section{TEKST ŹRÓDŁOWY}

[t. 42, s. 62] Rok 1918

[s. 62] Sobota, 5 stycznia

Rok ten rozpoczynam dość smutnie, gdyż w samego Sylwestra umarł Stanisław Tarnowski ${ }^{26}$. Wprawdzie nie bywałam u nich i żadnych bliższych stosunków z tym człowiekiem nie miałam, ale zawsze ceniłam go bardzo, a już od czasu kiedy tak łaskawie odpisał

${ }^{25}$ Tom 42 zawiera zapisy od 16 października 1917 r. do 29 maja 1919 r., liczy 408 stron, sygn. 29/1582/42 (dawna sygn. IT 428/42).

${ }^{26}$ Stanisław Tarnowski (1837-1917), historyk i krytyk literatury polskiej, czołowy przedstawiciel stronnictwa konserwatywnego. Od 1867 r. poseł na galicyjski Sejm Krajowy, od 1885 członek Izby Panów. W latach 1871-1909 profesor UJ (L. Rydel był jednym z jego uczniów), dwukrotnie rektor UJ. Jego pałac na Szlaku był ośrodkiem życia towarzyskiego. Zmarł 31 grudnia $1917 \mathrm{r}$. 
mi na mój list ${ }^{27}$, a przy tem własnoręcznie przypisał mi swoją broszurę o trylogii Lucjana ${ }^{28}$, do tej czci i szacunku przyłączyła się także i wdzięczność.

Lucjan odczuł jeszcze więcej tą // [s. 63] śmierć, bywając dość często w ich domu, a że Tarnowscy uważali go także za swojego przyjaciela, dali dowód w tem, iż go prosili, aby był na mszy św. przy zwłokach o godzinie pół do dziewiątej, na której cała rodzina się komunikowała, więc powiedzieli, że może i on jako tak wielki przyjaciel nieboszczyka zechce należeć do ich grona, co też rzeczywiście zrobił i przyjechał wcześnie z Bronowic.

Bardzo mi się to podobało, ale $\mathrm{z}$ drugiej strony jestem trochę o niego niespokojna, gdy bowiem nie wyszedł jeszcze z jednego zaziębienia i silnie kaszlał, a dzień pogrzebu był okropnie zimny i wietrzny, a gdy on naturalnie szedł na sam cmentarz piechotą, i gdy // [s. 64] dopiero o pół do drugiej powrócił on $\mathrm{z}$ tego pogrzebu ${ }^{29}$ do mnie i zaraz przebrawszy się tylko, pojechał na wieś, jestem więc w obawie, że się znowu zaziębił.

Gdy Tarnowski nie o wiele ode mnie starszy zamknął liczbę prawie wszystkich moich równienników, którzy przenieśli się już na tamten świat, tak że prócz starej Walterowej ${ }^{30}$ nikt prawie między moimi znajomymi w moim wieku już nie żyje, zdaje się więc, że i na mnie przyjdzie już niezadługo czas do odbycia tej ostatniej podróży.

Z tem wszystkiem gdy śniegi, które mnie obecnie bardzo ubezwładniają [!], stoją i wiosenne słońce nas przywita, to jeszcze przed podróżą na tamten świat będę chciała jeszcze nieraz zrobić wycieczkę // [s. 65] na ulicę Karmelicką, ażeby na kursach Baranieckiego

${ }^{27}$ W pierwszych dniach kwietnia 1910 r. A. Czechówna po przeczytaniu ostatniego tomu napisanej przez Stanisława Tarnowskiego Historii literatury polskiej, namówiona przez L. Rydla zdecydowała się napisać list do autora, bowiem w dziele tym znalazła potwierdzenie swoich negatywnych sądów o literaturze najnowszej. W kilka dni później otrzymała odpowiedź. Tarnowski napisał m.in. ,[...] składam Pani bardzo szczere gorące podziękowanie za te dobre słowa, które są i dobrem świadectwem. Może Pani i nie wyobrazi sobie jak miłego uczucia doznaje człowiek, który całe życie pisał, a często widział, że rzuca groch na ścianę, kiedy zobaczył, że są ludzie co tak myślą i czują jak on, i usłyszy jakieś przyjazne słowa, harmonijny akord własnych uczuć i myśli. [...] Ale cokolwiek dziś ludzie wymyślają i wypisują, niech Pani będzie pewna, że my mamy rację, nie oni. Przy nas jest prawda zdrowego rozumu, prawda poczucia i podziwiania piękności, i wreszcie prawda prostego nie spaczonego uczucia polskiego. [...]", zob. 29/1582/35, s. 235-238. W 1919 r. A. Czechówna tak skomentowała tę korespondencję: , ,... co się tyczy mojego listu do Stanisława Tarnowskiego i jego odpowiedzi. Że ten list mógł mnie bardzo ucieszyć, to łatwo zrozumieć, ale czy Tarnowski nie zagalopował się zbyt daleko, pisząc np. takie słowa, że »przy nas jest prawda zdrowego rozsądku i zrozumienie prawdziwego piękna«, to nie wiem. Słowa te przeważnie odnosiły się do Wyspiańskiego, z którym i on obszedł się bardzo surowo w swojej historii literatury i ja w tym pamiętniku”. A przecież „cała Polska, a szczególniej młoda Polska widzi w Wyspiańskim geniusz, a nawet narodowego proroka...”, ibidem, s. 230-231. Ostatecznie A. Czechówna przyznaje, że wraz ze Stanisławem Tarnowskim myliła się w swoich ocenach.

${ }^{28}$ Przypisał - w znaczeniu dedykował. Była to praca Stanisława Tarnowskiego, Zygmunt August. Trylogia Lucjana Rydla, Kraków 1912. A. Czechówna umieściła ją w tomie 37 swego „Dziennika” (sygn. 29/1582/37).

${ }^{29}$ Pogrzeb Stanisława Tarnowskiego odbył się w czwartek 3 stycznia 1918 r.

${ }^{30}$ Aniela z Klemensiewiczów Walterowa (zm. 1920), matka zmarłego w 1916 r. Władysława Waltera, właściciela Świdnika, zob. przyp. 10. 
posłuchać dalszego ciągu wykładów Lucjana o kulturze, a może jeszcze i innych działów literatury ${ }^{31}$.

\section{Wtorek, 8 stycznia}

Ponieważ zwykle spowiadam się przed tobą, mój przyjacielu [tu o „Dzienniku”] z każdej mojej myśli, z każdego zamiaru i z każdego uczucia, więc też muszę się przyznać przed tobą, że mi się dziwnie bez Lucjana przykrzy.

Kiedy jest w Krakowie, kiedy się spóźnia na obiad lub też postępuje sobie ze mną bardzo despotycznie, albo też znów wygaduje na kobiety, to się czasem i gniewam // [s. 66] na niego, ale gdy go długo nie widzę, a do tego gdy wiem, że te wakacje będą jeszcze długo trwały, a tem samem że jeszcze długo będę pozbawiona jego towarzystwa, i jeszcze długo nie będę miała z kim pomówić ani o książkach, które przeczytałam, ani podzielić się mojemi myślami, czy to z tego pamiętnika, czy też z polityki, to mnie opanowuje taka jakaś dziwna tęsknota, że to aż mnie przestrasza, bo gdyby też wskutek zmiany stosunków, o które teraz tak łatwo, wypadło im np. przenieść się do Warszawy lub Lwowa, wtedy jakże czułabym się osamotnioną, a nawet kto wie czy nie nieszczęśliwą. Do tej mojej tęsknoty przyczynia // [s. 67] się zapewnie i to że właśnie teraz czytam pamiętniki z r. [1]905 i następnych, gdzie to opisywałam, jakie wrażenie zrobiły na mnie jego wykłady o Ibsenie, a później u Baranieckiego, gdzie szeroko rozpisuję się, jak on jest dla mnie dobrym, jakie okazuje mi względy i jakie ze sobą prowadzimy rozmowy, toteż gdy to wszystko rozrzewnia mnie i obudza tem większe przywiązanie do niego, a tem samem obudza zarazem chęć zobaczenia się z nim i pomówienia. $[\ldots]^{\mathrm{a}}$

\section{[s. 68] [...] Niedziela, 13 stycznia}

Jak dalece samotność może być czasem bardzo niebezpieczną, jest najlepszym dowodem poprzedni artykuł.

Od wilii nie wychodzę, prócz do najbliższego kościoła, prawie nigdzie, gdyż śnieg z małemi przerwami ciągle pada, a przy tem jest tak ślizgo [!], że się na nogach utrzymać trudno. //

[s. 69] Śniegi te są zapewne przyczyną, że i Julcia Walterowa z Marysią nie przyjeżdża, a gdy do tego i towarzystwa Lucjana jestem pozbawioną, wywołało to we mnie taki smutny i pessymistyczny nastrój, iż gdy mnie ten trochę opuścił, roześmiałam się sama ze siebie.

${ }^{a}$ Opuszczono dalszy ciąg rozważań A. Czechówny dotyczacych przedlużającej się nieobecności L. Rydla

${ }^{31}$ Wyższe Kursy dla Kobiet, od 1891 r. Kursy im. Adriana Baranieckiego - prywatna placówka oświatowa utworzona w 1869 r. przez A. Baranieckiego (1828-1891) w Krakowie, z siedzibą przy ul. Karmelickiej 32. Kursy umożliwiały kształcenie się kobietom, pozbawionym wówczas możliwości studiowania na wyższych uczelniach. Nauka trwała dwa lata, a zajęcia odbywały się na wydziałach: historyczno-literackim, przyrodniczym, sztuk pięknych i gospodarczym. Dbano o wysoki poziom nauczania, w gronie wykładowców byli m.in. Maurycy Straszewski, Jan Matejko i L. Rydel, który w latach 1898-1916 prowadził zajęcia z literatury powszechnej, a następnie w latach 1916-1918 z historii kultury najnowszej. Absolwentki nie uzyskiwały jednak uprawnień państwowych. 
Ale co się tyczy polityki, to się wcale śmiać i cieszyć nie ma z czego. Niby to radzą o pokoju, ale z jakimże rządem? Czyż nie ze rządem rabusiów, który jawnie chce zabrać wszelką własność, a jak to wygląda w przykładzie widzimy, gdy // [s. 70] rozpuszczone wojska rosyjskie napadają na dwory, zabijają właścicieli, przeważnie Polaków, wszystko niszczą, grabią i już przeszło 300 wielkich majątków na Podolu i Wołyniu z ziemią zrównali.

A przykład ten działa zaraźliwie i już koło Radomia zbierają się wiece chłopskie i radzą wiele najwyżej morgów zostawić jednemu panu dziedzicowi, a wiele rozebrać między chłopów. Jednem słowem - żyjemy wśród największego przewrotu, jaki kiedykolwiek istniał na świecie. //

\section{[s. 71] Wtorek, 15 stycznia}

Wczoraj przyjechała Julcia z Marysią. Obie dobrze wyglądają i eleganckie jak zawsze. Poszły zaraz na raut tańcujący do Marsowej ${ }^{32}$, do mnie zaś przyszedł Henryk Kowalski z Klocią $a^{33}$. Stosunek między niemi zawsze naprężony, ale co mnie najwięcej martwi, to gdy widzę, że Henryk przy całej swojej zacności i poczciwości jest człowiekiem niereligijnym, nie chodzi do spowiedzi i dobrowolnie pozbawia się tylu łask. Nie jest to ateusz w rodzaju pułkownika Miłkowskiego ${ }^{34}$, który lubił występować przeciwko religii i Kościołowi. // [s. 72] Henryk nigdy tego nie robi, nigdy nie występuje z żadnemi zarzutami, ale cóż mi z tego, kiedy żyje poza Kościołem, a kiedym mu podarowała małą książeczkę z krótkiemi rozmyślaniami, napisaną przez księdza Siemińskiego „dla inteligencji” ${ }^{35}$, nie przyjął

${ }^{32}$ Być może Augusta z Żelechowskich Marsowa, wdowa po Leopoldzie (ur. ok. 1844).

${ }^{33}$ Henryk Wierusz Kowalski (1846-1929), syn Jana i Anastazji z Zielińskich, lekarz wojskowy. Studiował medycynę w Wiedniu na uniwersytecie oraz Akademii Wojskowo-Chirurgicznej (18671873). Następnie został lekarzem wojskowym armii austro-węgierskiej. Odbył staże naukowe w pracowniach Roberta Kocha w Berlinie, Ludwika Pasteura w Paryżu oraz higienisty Maxa Pettenkofera w Monachium (1873-1880), dzięki czemu był jednym z najwybitniejszych w Austrii znawców bakteriologii, epidemiologii i higieny. Został członkiem nadzwyczajnym Wojskowego Komitetu Sanitarnego przy Ministerstwie Wojny. Pomagał m.in. zwalczać epidemię cholery w Serbii (1886). W latach 1900-1906 otrzymał przydział najpierw do Sarajewa, następnie do Zary i Lubljany. We wrześniu 1906 r., przeniesiony w stan spoczynku, ponownie zamieszkał w Wiedniu. Podczas służby wojskowej doszedł do stanowiska Generalstabsarzta (generalnego lekarza sztabowego, tytularny generał major). Podczas I wojny światowej znowu znalazł się w służbie czynnej. Miał liczne rodzeństwo: Józefę (zm. 1919), Antoniego, Zygmunta i Tytusa oraz wspomnianą tu Klotyldę, nauczycielkę, następnie dyrektorkę szkoły w Nowym Sączu. Byli oni kuzynami A. Czechówny.

${ }^{34}$ Być może chodzi o Rudolfa Miłkowskiego (ur. ok. 1821), który pochodził z Sądeckiego. Za udział w powstaniu styczniowym zesłany został na Syberię Wschodnią (1863-1868). W lipcu 1869 r. wrócił do Galicji.

${ }^{35}$ Zapewne chodzi tu o ks. Jana Siemieńskiego (1836-1920), pisarza, działacza społecznego. Dużo podróżował. Pisał artykuły, początkowo na tematy religijne, później historyczno-filozoficzne, publikowane w pismach poznańskich, tarnowskich, warszawskich. Zainteresowania zbliżyły Siemieńskiego do środowisk literackich Krakowa, a później Lwowa. Interesował się życiem i twórczością Adama Mickiewicza. Pod koniec I wojny światowej osiadł w Krakowie. Poprzez swą twórczość szerzył wśród inteligencji poglądy katolickie, zyskując dużą popularność. Przypuszczalnie A. Czechówna ma tu na myśli jedną z jego prac, tj. Codzienne krótkie rozmyślania dla inteligencji, cz. 1-2, Kraków 1889; wyd. 2 Kraków 1902, wyd. 3 Kraków 1916. 
i powiedział, żebym dała Kloci. A przecież jest to książeczka, z której korzysta i Witold Rubczyński ${ }^{36}$ i Lucjan Rydel. [... $]^{\mathrm{a}}$

\section{[s. 73] [...] Ś Sroda, 16 stycznia}

Prócz wojny dzieją się obecnie straszne wypadki pozbawiające życia wielu ludzi i czyniące kalekami jeszcze więcej. Taki wypadek zaszedł właśnie wczoraj, gdy koło Rzeszowa zderzyły się dwa pociągi idące od Lwowa i do Lwowa. Szesnaście osób jest zabitych, a przeszło 50 ciężko rannych ${ }^{37}$. Do tych należą młodzi Kopaczyńscy, którzy wracali od rodziców z Lipnika ${ }^{38}$, gdzie było polowanie. Ona ma złamane obie nogi, on jedną, a drugą wywichniętą w kolanie. Wypadek ten zatrzymał Julcię w Krakowie, // [s. 74] gdyż chciała naturalnie odwiedzić ich kilka razy w sanatorium ${ }^{39}$, jako swoich przyjaciół, a nawet dalekich kuzynów, gdyż to przecie jest syn Śmiałowskiej, która była za Józiem Dzianottym z Olszany, a po jego śmierci poszła za Kopaczyńskiego ${ }^{40}$.

Już sam wypadek był strasznym, ale grozę jego powiększa jeszcze zachowanie się otaczających ludzi, którzy korzystając z tego wypadku, okradli ich i obrabowali. Jakiś oficer austriacki ukradł Witkowi strzelbę, ktoś inny porwał kuferek, a nawet ukradziono buty Witka i buciki Janki, gdy im nogi obandażowano. Ale i wtedy użyli niemało biedy, gdy ich wsadzono do wagonu towarowego, nie dano żadnej poduszki, chociaż się // [s. 75] o to prosili, i tak na twardem na pół żywych odwieziono do Krakowa, gdzie dopiero kazali się zawieźć do sanatorium, gdzie dr Rutkowski ${ }^{41}$ zaraz ich opatrzył.

\section{a Opuszczono dalsze przemyślenia A. Czechówny dotyczące H. Kowalskiego}

${ }^{36}$ Witold (Witołd) Rubczyński (1864-1938), filozof, historyk filozofii, od 1910 r. profesor filozofii na UJ. Zainteresowania W. Rubczyńskiego stopniowo przesuwały się ku filozofii systematycznej, której centrum stanowiła dla niego etyka. Na jego poglądach silnie zaważyły chrześcijańskie przekonania religijne. Był żonaty z Jadwigą Czermińską, z którą miał 3 córki i syna Stanisława, zmarłego 21 września 1917 r. w wieku 14 lat, zob. B. Lesiak-Przybył, Wielka wojna w „Dzienniku” Aleksandry Czechówny (część IV...), s. 210-211.

${ }^{37}$ Wypadek miał miejsce pod Trzcianą koło Rzeszowa.

${ }^{38}$ Witymir (Witek) Kopaczyński (ur. 1885), syn z pierwszego małżeństwa Franciszka Kopaczyńskiego (1849-1933) z Michaliną ze Śmiałowskich 1º v. Dzianottową (1857-1903). Wiosną 1914 r. Witymir poślubił Janinę Bielańską (ur. 1889), córkę Juliana i Michaliny z Komorowskich. W Bilczycach (pow. Wieliczka), które młodzi otrzymali prawdopodobnie jako wiano ślubne, zamieszkali oni zapewne tuż przed wybuchem I wojny światowej. Franciszek Kopaczyński niedługo po śmierci Michaliny ożenił się z Marią Wędrychowską. Lipnik - być może wieś w gminie Kańczuga, na południowy zachód od Przeworska.

${ }^{39}$ Tak mówiono o Domu Zdrowia, pierwszej prywatnej lecznicy w Galicji. Jej budowę, na rogu ul. Łobzowskiej i Siemiradzkiego, rozpoczął w maju 1888 r. lekarz Jan Kazimierz Gwiazdomorski (1854-1906), a otwarcie odbyło się w październiku 1889 r. Lecznica ta przez wiele lat była wzorem higieny i opieki.

40 Józef Dzianott (zm. 1875), przyrodni brat Ludwika (Ludwina) Dzianotta (ok. 1836-1894), męża Izabeli z Czechów $1^{\circ}$ v. Lisowieckiej (1842-1877), siostry Aleksandry. W 1873 r. ożenił się z Michaliną Śmiałowską, zob. przyp. 38.

${ }^{41}$ Maksymilian Rutkowski (1867-1947), chirurg. Studiował na Wydziale Lekarskim UJ (18861892), następnie został sekundariuszem w Szpitalu św. Łazarza na oddziale chorób wewnętrznych, a od 1894 r. na oddziale chirurgicznym. Od 1899 r. prowadził wykłady z chirurgii na UJ i habilitował się. W latach 1899-1903 pracował w lecznicy prywatnej, następnie jako ordynator oddziału chirur- 
Naturalnie, że i ja muszę ich odwiedzić, ale dopiero za kilka dni, gdyż obecnie są oni w takim stanie, że wszelkie dłuższe mówienie może im zaszkodzić.

Ale mam tu do zanotowania drugą smutną okoliczność. Z powodu braku chleba i w ogóle najsmutniejszej aprowizacji, która do rozpaczy doprowadza biedniejszą ludność, zaczynają się i w Krakowie rozruchy ${ }^{42}$, i gdy tylko się ściemni, liczne bandy napadają na sklepy, zabierają, // [s. 76] co się da, wybijają szyby, czynią wielkie szkody, a właściwie bez żadnego dobrego skutku, cóż bowiem winni im kupcy, że chleba nie mają.

Rezultat zaś tych rozruchów jest ten, że coraz trudniej jest coś dostać, gdyż wszystkie sklepy są ze zmierzchem pozamykane, i nie wiem tylko, co słychać z kawiarniami, i czy tam nie napadają ${ }^{43}$.

Rozruchy te mogą jednak mieć tę dobrą stronę, iż zwrócą uwagę wyższych władz na to, że nasza Galicja jest tak po macoszemu traktowana i wprost ogładzana [!], gdy wszystkie nasze produkta i węgle są masowo wywożone do Prus albo do Wiednia i następstwem tego jest u nas taka bieda i po prostu głód. //

\section{[s. 77] Sobota, 26 stycznia}

Lucjan nie ma tak długich wakacji, jak myślałam, gdyż wprawdzie u Baranieckiego nie ma jeszcze wykładów, ale ma gdzie indziej i dlatego co tygodnia zajeżdża do mnie na nocleg i obiad.

Kiedyś przyniósł mi zapiski, które zrobił o rodzinie Rydlów i Kremerów. Mówi, że to może da do druku i rzeczywiście są to rzeczy dosyć ciekawe i dobrze napisane, ale że są to rzeczy ściśle familijne, więc nie wiem doprawdy, czy się nadają do drukua . [...]

[s. 78] Ale i o sobie muszę tu zapisać rzecz niepomyślną. Ponieważ jeden Żyd, który ze Świdnika jeździł co tygodnia do Krakowa, wyjechał gdzieś na Morawy, a ponieważ przez niego Julcia, przysyłając pewne prowianty dla Marysi, przysyłała także i dla mnie pewne prowianty, a szczególniej masło, gdy więc tego Żyda zabrakło, jestem tego pozbawiona, a że co mięsne nic dostać nie można, więc zaczyna być ze mną coraz gorzej i tylko poczciwi Kowalscy jeszcze mnie ratują.

gicznego Szpitala św. Ludwika dla dzieci (1904-1908), a od 1908 r. był prymariuszem oddziału chirurgicznego Szpitala św. Łazarza. W 1910 r. otrzymał tytuł profesora nadzwyczajnego. Podczas I wojny światowej utworzył zespół chirurgów, tzw. grupę Rutkowskiego, działającą w szpitalach polowych w pobliżu linii frontu (1914-1916).

"A. Czechówna, czytając pod koniec 1919 r. ten tom „Dziennika”, dopisała poniżej: Były wydane zdaje mi się w „Czasie”, ale dopiero po jego śmierci. Rzeczywiście w wydaniach wieczornych „Czasu”, w okresie od 17 do 24 lipca 1918 r., na s. 1 wydrukowane zostaty kolejne części Wspomnień rodzinnych Lucjana Rydla ( $n r$ 306, 308, 310, 312, 314, 316, 318)

${ }^{42} \mathrm{~W}$ toku trwających 2 dni (14-16 stycznia) rozruchów spowodowanych brakiem żywności protestujący tłum wdarł się do gmachu Rady Miejskiej. 17 stycznia na Rynku odbyła się wielka demonstracja antywojenna.

${ }^{43}$ Rozporządzeniami nakazano zamykać kawiarnie o godz. 16, a po godz. 18 wolno było wychodzić z domu tylko w ważnych sprawach, por. Irena Homola-Skąpska, Życie codzienne w czasie I wojny światowej w dziennikach krakowskiego adwokata Klemensa Bąkowskiego, „Rocznik Biblioteki Naukowej PAU i PAN w Krakowie" 2005, R. 50, s. 330. 


\section{[s. 79] Wtorek, 29 stycznia}

Stan Jadwigi Rydlowej ${ }^{44}$ wymaga długiej, uciążliwej, a przede wszystkiem kosztownej kuracji. Co dzień chodzi do szpitala wojskowego w Bronowicach, gdzie jej zastrzykują jakieś preparata, a przy tem ciągle zażywa jakieś lekarstwa, a przy tem każą jej się tak dobrze odżywiać, jeść łyżeczkami deserowe masło, pić śmietankę, co wszystko w obecnych czasach kosztuje bajońskie sumy, iż mi serdecznie żal Lucjana. Wprawdzie ratuje go trochę Betleem $^{45}$, które ciągle ma niesłychane powodzenie, ale i to nie wystarcza. Najgorszem jest to, że on, szarpiąc // [s. 80] się na kurację żony, sam, jak mi to matka [Helena Rydlowa] ${ }^{46}$ mówiła, żyje w Bronowicach bardzo nędznie i wskutek tego coraz gorzej wygląda i znacznie zeszczuplał. A przecież i on jest po operacji ${ }^{47}$ i potrzebowałby innego pożywienia.

\section{$\underline{\text { Sobota, } 9 \text { lutego }}$}

Niesłychane rzeczy dzieją się w polityce. Państwa centralne wysyłają swoich ambasadorów, ażeby z bolszewikami reprezentującymi rząd rosyjski zawierać pokój. A temczasem cóż się dzieje? Ponieważ bolszewicy, to jest najskrajniejsi anarchiści, chcieli wciągnąć do swojego // [s. 81] wojska pułki polskie z dawnych legionów powstałe, a gdy te nie chciały im być posłuszne, chcieli ich rozdzielić i częściowo rozbroić. - Ale to im się nie udaje. Pułki polskie zebrane pod wodzą jenerała Muśnickiego, nie tylko że się nie rozdzielają, ale skupione pod dzielną komendą rzucają się na bolszewików, wszędzie ich pobijają, zabierają jedno miasto po drugiem, jak Mińsk, Mohylew, Smoleńsk ${ }^{48}$ i nawet samego ich dowódcę

${ }^{44}$ Jadwiga Rydlowa z Mikołajczyków (1883-1936), żona Lucjana Rydla jun. (1870-1918), matka Lucjana (1901-1957) i Heleny (1902-1969).

${ }^{45}$ W 1904 r. L. Rydel napisał dla teatrów ludowych patriotyczno-religijne jasełka Betlejem Polskie, których prapremiera odbyła się we Lwowie. W 1905 r. sztukę tę wystawił w Krakowie najpierw Teatr Ludowy (5 stycznia), później Miejski (27 grudnia). W zimie 1906-1907 Rydel zrealizował w Toniach przedstawienie z udziałem chłopów. Podczas I wojny światowej występujące w sztuce dzieci z Wrześni, z uwagi na sytuację i sojusz Austrii i Prus, zostały zastąpione przez rannych legionistów i uchodźców z terenów objętych działaniami wojennym, zob. B. Lesiak-Przybył, Wielka wojna w „Dzienniku” Aleksandry Czechówny (część III...), s. 146-147.

${ }^{46}$ Helena Rydlowa z Kremerów (1847-1921), córka Józefa i Marii z Mączyńskich, wdowa po Lucjanie (1833-1895), lekarzu, profesorze okulistyki i rektorze UJ. Matka Lucjana jun. (1870-1918), Adama (1872-1914), Heleny (1874-1920), żony okulisty Adama Langiego, Anny (1884-1969) oraz Mieczysława (1881-1899) i Stanisława (1891-1912).

${ }^{47}$ L. Rydel 31 stycznia 1917 r. przeszedł operację usunięcia lewej nerki, zob. B. Lesiak-Przybył, Wielka wojna w „Dzienniku” Aleksandry Czechówny (część IV ...), s. 191.

${ }^{48}$ Józef Dowbor-Muśnicki (1867-1937), absolwent Oficerskiej Szkoły Piechoty w Petersburgu (1888) i Akademii Sztabu Generalnego (1899-1902). Od 1912 r. szef sztabu 7 Dywizji Piechoty w Woroneżu (od 1914 r. w stopniu pułkownika), a następnie dowódca 14 Pułku Strzelców Syberyjskich (listopad 1914-wrzesień 1915). W sierpniu 1915 r. awansowany do stopnia generała majora, a w maju 1917 r. generała lejtnanta. Po rewolucji lutowej desygnowany przez Naczelny Polski Komitet Wojskowy w sierpniu 1917 r. objął dowództwo I Korpusu Polskiego w Rosji, polskiej ochotniczej formacji wojskowej podlegającej dowództwu rosyjskiemu. Wobec wybuchu rewolucji bolszewickiej formowanie korpusu nie zostało zakończone, a kiedy nowa władza zażądała jego likwidacji, rozpoczęto wojnę z bolszewikami (12 stycznia 1918 r.). 4 lutego 1918 r. powierzono mu naczelne dowództwo nad wszystkimi oddziałami Polskiej Siły Zbrojnej na Wschodzie i zdecydowano o ich koncentracji w rejonie Humań-Hajsyn. Realizację planu uniemożliwiły komplikacje polityczne 
Krylenkę ze sztabem biorą do niewoli ${ }^{49}$. Zwycięstwa te mieszają szyki całej Europy i psują ich plany swoją niespodziewaną nagłością.

[s. 82] Bo i z kimże tu właściwie konferować w tym Brześciu Litewskim. Czy z bolszewikami, którzy wszędzie są rozgromieni, czy też z jenerałem Muśnickim, który z dniem każdym staje się coraz większą potęgą. A wśród tego wszystkiego nienawiść do Prusaków wzrasta. We Lwowie zdzierają pruskie chorągwie i palą je $\mathrm{e}^{50}$.

Jednem słowem żyjemy wśród takiego zamętu i nieprzewidzianych niespodzianek, iż zdaje mi się, że i najgłębszy polityk nie może się w tym chaosie zorientować, a tem mniej nie może przewidzieć, co się jeszcze z tego chaosu wyłoni.

\section{[s. 83] Środa, 13 lutego}

Żyjemy w czasach, w których prawie każdy dzień przynosi nam coś nowego. I tak w tych dniach ogłosiły gazety, że Niemcy i Austria zawarły pokój z Ukrainą ${ }^{51}$, odstępując im naszą ziemię chełmską i Podlasie. Ponieważ stało się to po owych szumnych obietnicach Austrio-Niemiec, oburzenie więc wśród ludności polskiej jest powszechne. Wywołuje to wprost rewolucyjne objawy. Dom, gdzie był jakiś urząd pruski, zdemolowano, poturbowawszy urzędników, po ulicach przechodzą liczne pochody śpiewające albo nasze pieśni patriotyczne, albo [s. 84] krzyczące „hańba Niemcom”, biada zaś niemieckiemu wojskowemu, bo gdy tylko jego zachowanie nie spodoba się w czemkolwiek tłumowi, rzucają się na niego, łamią pałasze i czasem i poranią. Pozdzierali także wszędzie orły austriackie, portrety cesarza Karola ${ }^{52}$ popalono w szkołach wobec profesorów, jednem słowem oburzenie powszechne ${ }^{53}$.

$\mathrm{Na}$ poniedziałek zapowiedziane są jeszcze większe demonstracje, mowy na Rynku i pochód na Wawel. Oby to tylko nie pociągło nowych ofiar w ludziach, gdyż wszyscy są tak oburzeni tem wiarołomstwem Austrii i jej służalstwem względem Prus, że w jednym dniu Austria straciła całą naszą sympatię. [s. 85] Przekonaliśmy się, że na jej obietnice nic rachować nie można, a cesarz Karol, o którym tak wiele mówiono, jako o przyszłym królu polskim, okazał się tak nikczemną i przewrotną kreaturą, że dziś już żaden Polak zamiaru tego mieć już pewnie nie będzie.

$\underline{\text { Sobota, } 16 \text { lutego }}$

Żyjemy w strasznej, wprost tragicznej epoce. Nie tylko wszystkie nasze nadzieje padają jak domki z kart, ale trzeba się obawiać, aby nie przyszło do nowych ofiar i nowych

związane z zawarciem pokoju w Brześciu i rozpoczęciem przez wojska niemieckie marszu w kierunku wschodnim.

${ }^{49}$ Nikołaj Wasilewicz Krylenko (1885-1938), działacz partii bolszewików. Od 9 listopada 1917 r. komisarz ludowy ds. wojskowych i morskich (minister wojny) i Najwyższy Naczelny Dowódca wojsk rosyjskich.

${ }^{50}$ Dnia 2 lutego, z okazji kongresu Stronnictwa Pracy Narodowej, odbyła się we Lwowie wielka manifestacja zwrócona zarówno przeciw Niemcom, jak i Austrii. Doszło do starć z policją, których ofiarą padł uczeń gimnazjalny Marian Czerkas. Jego pogrzeb był olbrzymią manifestacją całego polskiego Lwowa.

${ }^{51}$ W dniu 9 lutego 1918 r. Niemcy i Austro-Węgry w Brześciu Litewskim zawarły traktat pokojowy z delegacją Centralnej Rady Ukraińskiej (Ukraińska Republika Ludowa), zob. przyp. 6.

${ }^{52}$ Karol I Habsburg, zob. przyp. 7.

${ }^{53}$ Zob. przyp. 8. 
nieszczęść. Jest rzeczą łatwo zrozumiałą, jak wszystkie umysły, a szczególniej też umysły młodych, są podniecone i jak wszystko w nich wre i kipi. [s. 86] Dopuszczają się też oni nie bardzo stosownych demonstracji, zrywają orły austriackie, zrywają i depczą portrety cesarza Karola, a wszystko to są rzeczy bardzo niebezpieczne. Na Rynku w poniedziałek zapowiada się wielka demonstracja. Ma być wypowiedziane 15 mów, ma być składana przysięga, że będziemy bronić całości i niezawisłości Polski ${ }^{54}$. Podnoszą się wprawdzie głosy wzywające do spokoju i żądające, ażeby ta demonstracja odbyła się bardzo poważnie i z godnością, ale czy się to uda? Czy wszyscy zdobędą [się] na ten spokój? A tu temczasem słyszę, że do Krakowa przyszli Prusacy, przyszli honwedzi z maszynowemi karabinami i z rozkazem nieprzepuszczenia nie publiczności. [s. 87] Jak więc odbędzie się ta manifestacja i czy nie sprowadzi nowych ofiar, Bóg tylko jeden wie.

W każdym razie przepaść między Niemcami a nami rozwarła się straszna, i tak z jednej strony, jak i z drugiej panuje nienawiść. Gazety niemieckie nie mogą zrozumieć, że my na te ich układy przystać nie możemy, a tem samem trzeba się spodziewać nowych prześladowań i nowych ucisków!

\section{Niedziela, 17 lutego}

Smutne czasy dla naszej Ojczyzny zeszły się ze smutnym stanem mojego zdrowia. Kiedyś w nocy dostałam bardzo silnych boleści, które mnie [s. 88] trzymały do samego rana, a nawet i rano jeszcze mnie bolało i nie mogłam być w kościele.

Przywołany dr Buzdygan ${ }^{55}$ powiedział, że był to silny atak artrytyczny [artretyczny?] i przepisał mi dłuższą kurację, każąc zażywać Uricedin-Stroschein.

Gdy rano Lucjan się obudził i jak zwykle wołał mnie do siebie, gdy od Kondy ${ }^{56}$ dowiedział się, co się stało, gniewał się bardzo, żeśmy go nie obudziły, że może przecie byłby co pomógł, albo i w nocy poleciał po doktora, jednem słowem był bardzo moją chorobą i zaniepokojony, i bardzo troskliwy.

Ja zaś to tylko wiem, że te przypadłości będą się już zapewnie częściej powtarzać.

[s. 89] Piątek, 22 lutego

Chociaż niezupełnie zdrowa, byłam jednak w poniedziałek na Rynku, bo też był to jeden z tych dni, których się nie zapomina ${ }^{57}$.

Wszystko odbyło się poważnie, majestatycznie, a jednak wśród tej całej uroczystości zbierało się na płacz. - Gdy bowiem wszystkie nasze nadzieje zostały tak haniebnie zawie-

\footnotetext{
${ }^{54}$ Wspólny Komitet polskich stronnictw wezwał obywateli miasta Krakowa do strajku w dniu 18 lutego 1918 r. oraz manifestacji patriotycznej w tymże dniu na Rynku głównym na znak protestu przeciwko decyzjom podjętym w Brześciu Litewskim, ANK, Zbiór afiszy i plakatów, sygn. 29/665/1476.

${ }^{55}$ Mikołaj Buzdygan (1851-1920), studiował na Wydziale Lekarskim UJ (1875-1882). W latach 90. był asystentem w Klinice chorób wewnętrznych dr. Edwarda Korczyńskiego w Krakowie. Pochowany został w Krzeszowicach. W jednym z tomów swojego pamiętnika Czechówna zamieściła jego fotografię wraz z komentarzem, że był bardzo zdolnym lekarzem.

${ }^{56}$ Kunegunda Janik (1849-1918), od 1888 r. służąca, najpierw w domu Aleksandry i Tomasza Czechów, następnie u Aleksandry Czechówny, która pisała o niej zawsze z wielką życzliwością.

${ }^{57} \mathrm{~W}$ dniu 18 lutego 1918 r. protestowano w całej Galicji. W Krakowie ogłoszono strajk powszechny i wielką narodową demonstrację, zob. też I. Homola-Skąp ska, Życie codzienne..., s. 331.
} 
dzionemi i gdy się przekonujemy, że o tyle tylko nam Polakom schlebiają, o ile nas potrzebują, a gdzie mogą, to krzywdzą, serce kraje się z boleści i jakże to smutnie, że podobnie jak w r. [18]63 musimy znów śpiewać „Boże!, policz te mogiły, te płaczące matki, żony!”\$8

Dla pamięci zapisuję tu także [s. 90] rotę przysięgi, na którą w poniedziałek 18 lutego przysięgaliśmy wszyscy na Rynku:

Wobec czynu bezprawia i przemocy, którym z żywego ciała Polski ma być oderwany odwieczny kawał ziemi polskiej, Chełmszczyzna i Podlasie, my Polacy zebrani na Rynku krakowskim w dniu 18 lutego 1918 r. zakładamy uroczysty protest przeciw temu nowemu rozbiorowi naszej Ojczyzny. Odwołujemy się do sumienia wszystkich wolnych i sprawiedliwych narodów świata i oświadczamy, że nie uznamy nigdy za prawo gwałtu, urągającego prawom boskim i ludzkim.

Piętnując obłudę i chytry plan wrogiej nam dyplomacji, wzniecania waśni między narodami, a wierząc niezłomnie w ostateczny triumf [s. 91] sprawiedliwości nad nagim gwałtem, ślubujemy, że póki tchu w piersiach, wszelkiemi środkami walczyć będziemy dla zdobycia zjednoczonej - niepodległej - i nieuszczuplonej Polski. Tak nam dopomóż Bóg!

\section{[s. 92] Piatek, 1 marca}

Najprzód muszę tu zapisać, że imieniny moje miałam bardzo przyjemne, a nawet jak na te smutne, a tragiczne czasy wcale korzystne, otrzymawszy różne rzeczy do jedzenia bardzo obecnie pożądane. Lucjanowa z Bronowic przywiozła mi pół kopy jajek, inne znów panie obdarzyły mnie jabłkami, konfiturami, marmeladą - jednem słowem rzeczy bardzo użyteczne. Jeden Lucjan obdarzył mnie strawą duchowną [!], gdy bowiem dowiedział się, że nie mam w mojej bibliotece Żywotów świętych Skargi, kupił mi takowych 12 tomików ${ }^{59}$ i ofiarował [s. 93] z następującą dedykacją: „Drogiej słuchaczce mojej i wychowanicy Aleksandrze Czechównie, w dniu imienin 26 II 918 r. składam z życzeniami pomyślności i zdrowia. Lucjan Rydel”.

W dzień imienin zaprosiłam na obiad także i Jadwisię z dziećmi, a ponieważ przyszli także i Tadziowie Kremerowie ${ }^{60}$, było więc bardzo wesoło, mimo tych smutnych czasów,

${ }^{58}$ Cyfrowa Biblioteka Polskiej Piosenki podaje cztery tytuły tej pieśni: Boże Ojcze, Twoje dzieci; Boże Ojcze; Modlitwa narodowa, Modlitwa. Pieśń powstała w 1838 r., a za jej autora uważa się Marcelego Skałkowskiego. Czasem jako autor podawany jest ks. Karol Bołoz Antoniewicz, http://www. bibliotekapiosenki.pl/utwory/Boze_Ojcze_Twoje_dzieci (odczyt: 14.03.2018).

${ }^{59}$ Żywoty świętych Starego i Nowego Zakonu [...], wybrane z poważnych pisarzów i doktorów kościelnych, pierwsze wydanie - Wilno 1579. Dokonana prze Piotra Skargę (1536-1612), jezuitę, nadwornego kaznodzieję Zygmunta III, przeróbka sześciotomowej pracy niemieckiego hagiografa Laurentiusa Suriusa, skrócona do jednego obszernego tomu i wzbogacona o informacje z prac innych hagiografów katolickich oraz dodane od siebie żywoty polskich świętych i błogosławionych. Dzieło cieszyło się ogromną poczytnością i uznaniem niezmiennie od chwili wydania aż do połowy XX w. (8 edycji za życia autora i ponad $20 \mathrm{w}$ następnych stuleciach).

${ }^{60}$ Tadeusz Kremer (ur. 1883), syn Józefa Kremera (1848-1906), prawnika i Heleny z Epsteinów, kuzyn Lucjana Rydla jun. W 1903 r. zdał egzamin maturalny w gimnazjum w Nowym Sączu i podjął studia na UJ. W listopadzie 1911 r. uzyskał uprawnienia do nauczania języka polskiego (przedmiot główny) i filologii klasycznej (przedmiot poboczny) w gimnazjum. W końcu sierpnia $1913 \mathrm{r}$. w Samborze odbył się jego ślub z Zofią Biegelmayerówną. Z uwagi na stan zdrowia żony od 1916 r. przebywał w Krakowie. 
i mimo tego że panowie prosto z obiadu poszli na pogrzeb Pareńskiej, która umarła, nie doczekawszy się późnej starości, i umarła nieprzytomnie na zwapnienie żył mózgowych ${ }^{61}$.

Co do mnie, to wszyscy byli nadzwyczaj dla mnie serdeczni, ale wszystkich przeszedł Lucio, który doprawdy czasem mnie i [s. 94] zadziwia swojem przywiązaniem, nadając mi różne pochlebne nazwy, a przy tem całując mnie tylko ciągle po rękach i nie chcąc być w domu ani jednej minuty bez mojego towarzystwa. $[\ldots]^{\mathrm{a}}$

\section{[s. 95] [...] Niedziela, 3 marca}

Lecz nie zawsze Lucjan daje mi tak przyjemne chwile, gdyż przeciwnie uważam, że gdy tylko on w tych objawach przyjaźni trochę się zagalopuje, [s. 96] wtedy najczęściej występuje z niegrzecznościami, a nawet wprost z impertynencjami, które wprawdzie nie odnoszą się do mnie jako do Aleksandry, ale odnoszą się ogólnie do kobiety. „Wszystkie jesteście mało warte - mówi wtedy Lucjan - toteż wszystkie największe gieniusze [!] poznały się na was. Szekspir w Hamlecie mówi: »Słabości imię Twoje kobieta«, Mickiewicz nazywa was marnym puchem. Wiktor Hugo powiada, że »la femme rime à l'infame « ${ }^{62}$. Ekleziastyk powiada »a ramiona jej, sidła rozciągnięte. Kobieta to brama piekielna, więc strzeżcie się jej«. Lecz na co przytaczać sławnych [s. 97] ludzi i mędrców, kiedy sam Pan Bóg dostatecznie was upokarza, choćby tylko w 10 przykazaniach: Nie pożądaj żony bliźniego twego, dodając natychmiast ani wołu, ani osła, ani żadnej rzeczy, która jego jest, a tem samem mówi Rydel - ani prosięcia, ani gęsi, ani miotły itd., itd. Wprawdzie Pan Bóg kładzie was na pierwszem miejscu, ale zawsze jakby w jednym ciągu z wołem, osłem i miotłą”. - I cóż tu na to powiedzieć? Gdy ja jestem za słabą w argumentacji, a tem samem nie umiem zbić tych twierdzeń, zapisuję więc tylko te piękne komplementa, pozostawiając ich zbijanie przyszłym czytelnikom mojego pamiętnika.

\section{[s. 98] Piatek, 8 marca}

Przeczytałam w tych czasach dwie powieści: Soból i panna Weyssenhoffa ${ }^{63}$ i Wesoła teoria i smutna praktyka Orzeszkowej ${ }^{64}$. [... $]^{\mathrm{b}}$

${ }^{a}$ Opuszczono fragment, w którym A. Czechówna opowiada, jakie pretensje ma do niej L. Rydel, kiedy nie przyjdzie na prowadzony przez niego wykład

${ }^{\mathrm{b}}$ Opuszczono pozytywna ocenę A. Czechówny dotyczaca powieści J. Weyssenhoffa. Pamiętnikarka zachwyca się pięknymi opisami krajobrazów i polowań. Uznaje, że powieść E. Orzeszkowej jest dobra pod względem wychowawczym, ale przestarzała, jeśli chodzi o forme

${ }^{61}$ Eliza Pareńska, żona Stanisława, z domu Mükleisen (1857-1918), protektorka cyganerii krakowskiej. U Pareńskich w ich mieszkaniu przy ul. Wielopole oraz w willi „Eliza” w Tenczynku spotykała się elita intelektualna i artystyczna Krakowa tego czasu. Szczególnie zaprzyjaźniony z Pareńskimi był Stanisław Wyspiański, nad którym Stanisław Pareński sprawował również opiekę lekarską. Córki Pareńskich: Maria i Zofia były pierwowzorami Maryny i Zosi z Wesela. Mieli też syna Jana (lotnika, zginął podczas wojny polsko-ukraińskiej) i najmłodszą Elizę. Eliza Pareńska zmarła 14 lutego, została pochowana 27 lutego na Cmentarzu Rakowickim.

${ }^{62}$ la femme rime à l'infâme (franc.) - wykorzystanie rymu: femme - infâme (kobieta - niegodziwy/zhańbiony); dosł. kobieta rymuje się z niesławnym.

${ }^{63}$ Soból i panna, powieść obyczajowa napisana przez Józefa Weyssenhoffa (1860-1932) w 1911 r.

${ }^{64}$ Powieść Wesoła teoria i smutna praktyka została napisana przez Elizę Orzeszkową (18411910) w $1872 \mathrm{r}$. 
Ale zamiast o powieściach pomówmy lepiej o wykładach Lucjana. [s. 99] Jest to doprawdy rzecz szczególna, że kiedy wśród tej wojny odeszła mnie zupełnie ochota chodzenia do teatru, a i na koncert trudno mi się wybrać, zwłaszcza że sala Starego Teatru jest zajęta na szpital, a koncerta odbywają się w dalekim Sokole, jedne wykłady Lucjana mają zawsze równy dla mnie powab i zawsze bardzo mnie zajmują.

Ponieważ na drugim kursie rozpoczął on historię literatury osiemnastego wieku we Francji, gdy więc godziny są mi dogodne, biorę więc dwie godziny dziennie i tym sposobem słucham kultury i historii literatury osiemnastego wieku, a kiedy wychodzę, zadaję [s. 100] sobie zwykle pytanie, który wykład był więcej zajmującym i który mi się więcej podobał, ale zwykle pytanie nie zostaje rozwiązanem, gdyż oba wykłady są bardzo zajmujące, toteż myślę, że nie dam powodu Lucjanowi do takich gniewów i złości, gdyż gdy tylko zdrowie mi dopisze, postanowiłam chodzić pilnie do końca kursu.

W kulturze mówił on o wieku szesnastym, a więc o Odrodzeniu, Medyceuszach, o ich walkach z rodziną Pazzich, zaś na historii literatury dał nam wspaniałą charakterystykę osiemnastego wieku, który podobnie jak i wiek szesnasty burzył wszystkie ideały i wszystkie wierzenia średniowieczne, ta jednak zachodzi różnica, [s. 101] że kiedy renesans dał nam w zamian prawdziwe arcydzieła, wiek osiemnasty nie dał nam nic, a przynajmniej bardzo mało. $[\ldots]^{\text {a }}$. Jednem słowem ów wielki Voltaire zmalał cokolwiek po wykładzie Lucjana.

\section{[s. 102] Sobota, 9 marca}

W uzupełnieniu mojego wczorajszego sprawozdania dodać tu muszę, tę pocieszającą dla nas katolików prawdę, że mimo całej okropności obecnej wojny, i mimo całej podłości rządów, i oszukańczej dyplomacji, możemy jednak tem się pocieszać, że przynajmniej Kościół nasz jest czystym, a duchowieństwo zacne i ofiarne. Czyż bowiem nie tylko u nas w Polsce, ale w całym świecie katolickim, mógł obecnie zdarzyć się wypadek, który szczegółowo opisywał Lucjan na wykładzie kultury renesansowej? [... $]^{\mathrm{b}}$

\section{[s. 104] Wtorek, 12 marca}

Mam znowu nowe awantury i przejścia z Lucjanem. - Nieraz po obiedzie, położywszy się na szezlongu i każąc mi siedzieć przy sobie, gdy trzecia godzina się zbliża, wtedy on przeciągając się, mówi: ,ach moja droga jakże mi się iść nie chce, chyba że ty pójdziesz ze mną, a wtedy zobaczyłabyś, jak ślicznie wykładałbym ci o Grecji”. - Ponieważ wykłady te ma on w Szkole Sztuk Pięknych dla artystów, więc naturalnie ja się tylko śmieję i nie idę.

Ale wczoraj przyszedł on z propozycją, że ponieważ on te wykłady przenosi do kościołów, a jak na początek do krypty wawelskiej, gdzie są groby, więc par force ${ }^{65}$ nie tylko

${ }^{a}$ Opuszczono fragment, w którym A. Czechówna powtarza opinię L. Rydla, który chwali twórczość Monteskiusza (1689-1755) i Voltaire'a (1694-1778), krytykujac jednak tego drugiego za kontrowersyjne postępowanie

b Opuszczono fragment, w którym A. Czechówna przytacza okoliczności zamachu przeprowadzonego w niedziele wielkanocna (26 kwietnia 1478 r.) w katedrze florenckiej, który miat na celu odsunięcie Medyceuszy od rządów we Florencji. Zwłaszcza martwi ja fakt, że miejscem zamachu byt kościót, $i$ że uczestniczyli w nim duchowni. Wyraża też przekonanie, że dziś takie zdarzenie nie jest możliwe

${ }^{65}$ Par force (franc.) - gwałtem, przemocą, bezceremonialnie. 
mnie namawia, ale wprost nakazuje, ażebym jutro przy obiedzie była [s. 105] gotową, gdyż o trzeciej muszę z nim jechać tramwajem na Wawel. Na próżno tłomaczę i proszę się, żeby mnie od tego uwolnił, że to jest dla mnie utrudzające, i że kiedy ma mnie już na pięciu godzinach u Baranieckiego tygodniowo, to już powinien być zadowolonym. On na to wszystko odpowiada, że nie przyjmuje żadnych tłomaczeń, żadnych wykrętów, i że jutro żeby mnie miał na rękach zanieść, to mnie zaniesie do krypty. Jeszcze jutro będę się starała od tej wycieczki uwolnić, ale on jest tak upartym, że nie wiem doprawdy, kto z nas ustąpi. Kiedy chwalę jego wykłady u Baranieckiego, które są rzeczywiście wspaniałe, i o których pomówię znów innym razem, wtedy on mówi ,wierzaj mi, że ja // [s. 106] wtedy tylko umiem tak mówić, gdy ty jesteś na wykładzie, i gdy mówię wyłącznie do ciebie, bo gdy twój stołek pusty, to i wykład jest o wiele słabszym”. - I niechże mi kto wytłomaczy tę zagadkę. Że ja lubię jego towarzystwo, jego wykłady, które mi dają tyle prawdziwej rozkoszy to jasne i łatwe do zrozumienia, ale żeby on, który ma przed sobą tyle słuchaczek, i to ślicznych panien, miał dbać o taką staruszkę i to jeszcze o takie zero, to doprawdy dziwne.

\section{[s. 107] Piatek, 15 marca}

Stało się tak, jak przypuszczałam, bo gdy mi powiedział, że zrobię mu największą w świecie przykrość, gdy na Wawel nie pójdę, a gdy nadto dodał, że jeżeli ja sama przyznaję, że on mi robi wiele przyjemności swojemi wykładami, to już podobno zasłużył, ażebym chociaż niechętnie zrobiła dla niego tę ofiarę i pojechała z nim na Wawel. I cóż było robić? Musiałam ustąpić i przed trzecią wsiedliśmy do tramwaju, z którego bardzo troskliwie mnie wysadzał i zabawiał rozmową, bojąc się, abym nie skaprysiła i nie wsiadła do tramwaju powracającego do domu, ile że śnieg zaczął padać i zrobiło [s. 108] się zimno i wietrzno.

Gdy wychodziliśmy na górę, powiedział mi, że przed nami idzie księżna Radziwiłłowa, Potocka, Tarnowska, jednem słowem wiele pań z arystokracji, które dowiedziawszy się, że będzie miał wykład, przyszły na zamek.

Najpierw zaprosił nas do krypty, gdzie są groby, sprowadziwszy mnie troskliwie na dół. W krypcie naturalnie nie ma żadnych ławek, toteż ja byłam w obawie, jak ja tam wystoję albo niewygodnie przykucnę przy jakim nagrobku, na co musiały przystać te wszystkie magnatki, gdy jednak Lucjan zaczął tylko mówić, jakiś mężczyzna [s. 109] wysunął się spoza nagrobku Kościuszki i podał mi wygodne krzesło, na które, jak uważałam, z pewnem zadziwieniem, ale z pewnością i nie bez zazdrości spojrzały moje towarzyszki. O wykładzie Lucjana niewiele mam do powiedzenia, gdyż mówił właśnie o krypcie, gdzie się znajdujemy, o dawnym Wawelu, który prawdopodobnie był drewnianym, a według wszelkiego prawdopodobieństwa Skałka była właściwie katedrą, i dlatego to S. Stanisław został tam zamordowanym. Naturalnie, że wszystko wypowiedział on ładnie, nie powiem jednak, aby zajął mnie tak jak historią kultury i literatury.

[s. 110] Skończywszy swój wykład w krypcie, wyprowadził nas później na dziedziniec, gdzie nam pokazał basztę w stylu romańskim, a następnie powiedział, że pójdzie do kancelarii dowiedzieć się, czyby nie można zobaczyć nowo odkopanej świątynki, która mogła być postawiona za czasów Chrobrego, albo nawet przerobiona z jeszcze starszej pogańskiej świątyni. Ponieważ śnieg zaczął padać i było mi zimno, bojąc się, aby on przy zwiedzaniu tych ruin nie zatrzymał mnie zbyt długo i nie naraził na jakie karkołomne schodzenie, dałam drapaka, kiedy on poszedł do kancelarii, ale źle na tem wyszłam, gdyż najprzód wystałam się na śniegu, [s. 111] nie dostałam miejsca w przepełnionych tramwajach i jak 
niepyszna musiałam piechotą dybać ${ }^{66}$ do Rynku, gdzie dopiero zdobywszy tramwaj, powróciłam do domu.

Ale gorsza była przeprawa z Rydlem nazajutrz rano: „Ach ty niegodziwa lekkomyślna dziewczyno, coś ty mi wczoraj zrobiła. Przyszedłszy do kancelarii, widzę na stole model w miniaturze tej odkopanej świątyni pod wezwaniem S. Andaukta $[!]^{67}$. Zdobywszy stołek, myślę z przyjemnością, jak cię na nim wygodnie posadzę i na tym modelu będę Wam prawił o stylu romańskim. Wychodzę ucieszony, rozglądam się, a ciebie niewdzięcznico już nie ma. I dlaczegoś mi to zrobiła? [s. 112] A szczególniej coś na tem zyskała? Zamiast słuchać mojego wykładu w ciepłym pokoju i na wygodnym krześle, stałaś na śniegu, na wietrze i w końcu piechotą poszłaś do miasta. Gdybyś zaś była mnie się trzymała, byłbym ci wszystko inaczej ułatwił. Pamiętaj więc moja córuchno na drugi raz nie buntować mi się, być mi posłuszną, uległą, a wtedy zawsze dobrze wyjdziesz". Tyle więc co do naszej wycieczki na Wawel. [... $]^{\mathrm{a}}$

\section{[s. 115] Niedziela, 17 marca}

$\mathrm{Z}$ nowin rodzinnych muszę tu zanotować wiadomość, że Stasia Noëlowa ${ }^{68}$ jest przy nadziei i spodziewa się rozwiązania w sierpniu. Według tego co mi Julcia mówiła, poddała się ona pewnej małej operacji we Lwowie i następstwem tejże jest jej stan dzisiejszy. Nie wiem, czy mam się z tego cieszyć, czy też smucić, gdy bowiem jest to kobieta czterdziestoletnia i już piętnaście lat jak poszła za mąż, teraz wśród wojny narażać się na takie awantury, jest to doprawdy cokolwiek ryzykowne, ale gdy chciała koniecznie zostać mamusią, niechże nią będzie, oby tylko ta awantura nie skończyła się tragicznie.

\section{[s. 116] Piatek, 22 marca}

Chcąc znów choć kilka słów poświęcić wykładom Lucjana, wspomnę, że w tym tygodniu na literaturze mówił o teatrze Marivaus ${ }^{69}$, a chociaż jego osoby są zmanierowanemi figurkami porcelanowemi, mają jednak swój własny wdzięk. [...]

a Opuszczono streszczenie wyktadu L. Rydla z zakresu historii literatury, podczas którego rozważat on różnice pomiędzy twórczościa Voltaire'a a Jean-Jaques'a Rousseau (1712-1778), którego można uważać za ojca romantyzmu. Opuszczono również streszczenie wyktadu L. Rydla podczas zajęć $z$ historii kultury o wplywie antyku na renesans

${ }^{\mathrm{b}}$ Opuszczono dalszy ciag streszczenia wyktadów L. Rydla z historii literatury, który omawial twórczość wybitnych przedstawicieli francuskiej i niemieckiej literatury: Pierre'a Beaumarchais'ego (1732-1799), Gottholda Ephraima Lessinga (1729-1781), Christopha Martina Wielanda (17331813) i Johanna Gottfrieda Herdera (1744-1803), a na wyktadzie z historii kultury przedstawit postać Hieronima (Girolamo) Savonaroli (1452-1498) i komentarze A. Czechówny

${ }^{66}$ Dybać - tu w znaczeniu iść lub jechać dokądś

${ }^{67}$ W 1917 r. podczas prac restauracyjnych na Wawelu Adolf Szyszko-Bohusz (zob. przyp. 71) dokonał ważnego odkrycia archeologicznego - natrafił na pozostałości przedromańskiej rotundy św. św. Feliksa i Adaukta. Według jego projektu zostały one zrekonstruowane i w 1918 r. udostępnione zwiedzającym.

${ }^{68}$ Stanisława z Dzianottów Noëlowa (ur. 1877) była córką Izabeli z Czechów, siostry Aleksandry i Ludwika (Ludwina) Dzianotta, od 1901 r. żoną Adama Noëla, który dzierżawił w tym czasie majątek w Komborni, miejscowości położonej ok. 9 km na północny wschód od Krosna.

${ }^{69}$ Pierre Carlet de Chamblain de Marivaux (1688-1763), jeden z najważniejszych dramaturgów francuskich, tworzący w pierwszej połowie XVIII w. Jego sztuki wystawiano głównie w Comédie- 
[s. 118] [...] A teraz ze środowego wykładu na Wawelu. Naturalnie nie będę tu się rozpisywała, co on mówił o gotyckim stylu, podniosę tylko to, co mnie więcej uderzyło. Otóż gotyk francuski różni się dlatego od polskiego, iż tam przeważnie używano marmuru, o który było łatwiej, u nas zaś musiano go zastępować cegłą. Dalej zwrócił naszą uwagę na drzwi katedry, na których przechowała się jeszcze wyraźnie litera $\mathrm{K}$ z koroną, świadcząca, że drzwi te, a raczej pewnie blacha na nich, pochodzą od Kazimierza Wielkiego. Przy nagrobku Łokietka dowiedzieliśmy się dalej, że kiedy Virchov ${ }^{70}$ [?] był w Krakowie, był tak zachwycony głową tego króla, iż kazał ją sobie kilka razy fotografować, jako idealnym typem słowiańskim.

[s. 119] Przy sarkofagu Kazimierza Wielkiego prawił nam znów o jego fryzurze, która wtedy była modną, jak również i o jego długich zagiętych butach, tak niewygodnych w chodzeniu, iż czasem przy przesadnej ich długości musiano podwiązywać takowe sznureczkami, albo też łańcuszkami, których końce ówcześni eleganci trzymali w rękach.

Po wykładzie Lucjan, niezmiernie zadowolony żem z nim przyjechała na Wawel, zaprowadził mnie samą do kancelarii, gdzie mi pokazał ów ciekawy model odkopanej świątynki S. Adaukta. Poznałam tam także p. Szyszko-Bohusza, owego budowniczego, który tak starannie zajmuje się restauracją Wawelu ${ }^{71}$. [... $]^{\mathrm{a}}[$ s. 120] [...] Po wykładzie nie chciał się ze mną rozłączyć i towarzyszył mi plantami, poczem on poszedł do matki, a ja zaś do Zmartwychwstańców na konferencję rekolekcyjną księdza Petryki ${ }^{72}$.

\section{[s. 121] Ś Sroda, 24 marca}

Smutne bardzo będę miała święta, gdyż dwóch moich najlepszych przyjaciół pochorowało się. Najprzód rozchorował się Henryk Kowalski. Kiedyś upadł na ziemię i przez dwie godziny był zupełnie nieprzytomny, a jakkolwiek ma się lepiej, zawsze jest to stan niedobry. Jest to także bardzo smutnem, że oboje, to jest Klocia i on nie mogą się jakoś zgodzić, ciągle sprzeczają się ze sobą, a nawet Klocia chce się od niego wyprowadzić. Nie wiem jednak, czy to nastąpi wobec jego choroby.

-Italienne, ale i w Comédie-Française w Paryżu. Najważniejsze jego dzieła to: Surprise de l'amour (1722), Triomphe de Plutus (1728), Le Jeu de l'Amour et du Hasard (Igraszki trafu i miłości, 1730) i Les Fausses Confidences (1737). Opublikował też wiele esejów oraz dwie niedokończone powieści.

a Opuszczono fragment, w którym A. Czechówna opowiada o opiece, jaka ja otoczyt L. Rydel podczas zwiedzania Wawelu

${ }^{70}$ Być może Rudolf Virchow (1821-1902), niemiecki patolog, antropolog i higienista.

${ }^{71}$ Adolf Szyszko-Bohusz (1883-1948), architekt i konserwator. W latach 1910-1912 wykładał na UJ i w ASP w Krakowie, a w latach 1912-1916 na Politechnice Lwowskiej. W 1916 r. powrócił do Krakowa i objął stanowisko kierownika prac restauracyjnych, następnie kierownika Odbudowy Zamku Królewskiego na Wawelu (1916-1939, 1945-1947). Od 1920 r. profesor UJ i kierownik Katedry Architektury Zabytkowej w ASP. Jako architekt projektował głównie obiekty użyteczności publicznej, kamienice, wille.

${ }^{72}$ Prawdopodobnie był to ks. Piotr Pietryka (1879-1927), zmartwychwstaniec (wstąpił do zakonu w 1898), śluby zakonne złożył w 1899 r. Składam w tym miejscu bardzo serdeczne podziękowania ks. Jerzemu Rolce CR, dyrektorowi Archiwum Prowincji Polskiej Zgromadzenia Zmartwychwstańców w Krakowie za życzliwość i merytoryczną pomoc. 
Lecz jeszcze więcej od choroby Henryka zaniepokoiła [s. 122] mnie choroba Lucjana. Kiedyś przyjechała tu Helenka, jego córka ${ }^{73}$, i powiedziała mi, że ojciec jest chory, ma silną gorączkę i lekarz ze szpitala w Bronowicach bardzo się obawia, aby nie przyszło zapalenie płuc. Możesz łatwo odgadnąć, jak mnie ta wiadomość przeraziła, tem więcej, że sobie przypominałam, jak na Wawelu był on mizernym, gdyby więc obecnie przyszła jaka ciężka choroba, czyż on ją przetrzyma?

Lecz i inne okoliczności przyczyniają się do zatrucia mi zbliżających się Świąt. Najprzód i mnie noga boli, i nie pozwoli mi wiele chodzić, [s. 123] następnie po kilku bardzo ładnych i ciepłych dniach prawdziwie wiosennych nastała znów zima z mrozami i śniegiem, a gdy do tego gazety donoszą, że niemieckie armie odnoszą niebywałe zwycięstwa na Anglikach i Francuzach, co właśnie dla nas jest bardzo niekorzystnem, wszystko to więc razem działa tak deprymująco, iż gdyby nie religia i nie modlitwa, można by popaść w stan prawdziwie rozpaczliwy!

W końcu muszę tu zanotować, że gdy za pierwszą naszą na Wawelu bytnością jeden z jego [L. Rydla] uczni odbił naszą grupę przy wejściu do katedry, której egzemplarz dostałam, zamieszczam więc takowy na końcu pamiętnika.

\section{[s. 124] Wielki Piatek, 29 marca}

Lucjan jest ciężko chory. Ma zapalenie płuc. Prócz Hani ${ }^{74}$, która co dzień tam jeździ, bawią tam aż dwie pielęgniarki, ażeby się mogły zmieniać w nocy. Teraz dopiero widzę, jak Konda była obrotna podczas choroby mamy. Przecież mama, chorując na skira ${ }^{75}$ przez półtora roku, potrzebowała więcej opieki i pielęgnacji niżeli przy zapaleniu płuc, a jednak tylko Konda ze mną musiałyśmy dawać sobie we wszystkiem radę, tam zaś chociaż jest żona i córka prawie że dorosła i nie mająca obecnie żadnych wykładów, nawet przy pomocy Hani nie dają sobie rady.

\section{[s. 125] Poniedziałek Wielkanocny, 1 kwietnia}

Straszne Święta! Lucjan jest umierający! Właśnie przed chwilą wpadł do mnie Tadzio Kremer, który z Bronowic powracał. Nie taił przede mną, że zastał Lucjana zmienionego do niepoznania. Podobno z płucami jest lepiej, ale serce tak szybko słabnie, iż na gwałt posyłają po koniak, aby tętno podtrzymywać. Jednem słowem widzę, iż trzeba chyba cudu, ażeby on przyszedł do zdrowia. Jaki to jest cios dla mnie, nie potrzebuję chyba pisać i kto będzie czytał te pamiętniki, ten będzie musiał mi przyznać, że jeżeli ten człowiek [s. 126]

${ }^{73}$ Helena Rydlówna (1902-1969), córka Lucjana Rydla (1870-1918) i Jadwigi z Mikołajczyków (1883-1936), miała brata Lucjana (1901-1957). W 1928 r. poślubiła swego dalszego kuzyna Zdzisława Rydla i zamieszkała w dworku bronowickim.

${ }^{74}$ Anna Antonina Rydlówna (1884-1969), córka Lucjana Rydla sen. i Heleny z Kremerów, siostra Lucjana, poety, Adama, lekarza psychiatry, Heleny Langie. Podczas wojny, razem z Marią Epsteinówną (1875-1947), działała jako instruktorka szkoły pielęgniarskiej w założonym w styczniu $1915 \mathrm{r}$. przez biskupa Adama Sapiehę (1867-1951) Książęco-Biskupim Komitecie Pomocy dla Dotkniętych Klęską Wojny (zwanym KBK) w sekcji sanitarnej, kierowanej przez prof. Emila Godlewskiego jun. (1875-1944).

${ }^{75}$ Skir - dawne medyczne określenie raka. 
umrze, będzie to największe nieszczęście, jakie mnie spotyka w życiu. Ze siostrą ${ }^{76}$ nie łączyło mnie zbyt wielkie przywiązanie. Rodziców kochałam, ale gdy umierali, byli to ludzie starzy, schorowani, cierpiący, od których już się żadnej pomocy spodziewać nie mogłam. Ale ten człowiek, który jeszcze tak niedawno był zupełnie zdrowym, i który jakby na pożegnanie okazywał mi w ostatnich czasach tyle przyjaźni i tyle serdeczności, ten człowiek, od którego tyle się jeszcze spodziewać mogłam, gdy więc ten człowiek umiera, nie jestże to największe nieszczęście, jakie mnie spotkać mogło. Ale nie rozpaczajmy i przyjmijmy ten krzyż z pokorą.

\section{[s. 127] Środa, 3 kwietnia}

Podobno Lucjanowi jest trochę lepiej, a którą to wiadomość przywiózł mi wczoraj poczciwy Tadzio Kremer.

Także wczoraj odebrałam kartę od Lucjana. Pisana ołówkiem, bardzo niewyraźnie, widocznie drżącą ręką, tak że niektórych słów tylko się domyślić mogłam. Jest ona przy tem wszystkiem żartobliwa, ale ponieważ mimo tego może być ostatnią, dlatego odpisuję ją tutaj:

Kochana lekkomyślna dziewczyno! Ty masz lat 78. Idziesz sobie na drugi koniec miasta, do Promińskich ${ }^{77}$ na obiad proszony, a ja mam [s. 128] lat 48 i w tymże samym dniu (to jest w niedzielę wielkanocną) przyjmuję wiatyk, ostatnie oleje na wszelki wypadek. A co? Kiedy twierdzę, że ty wszystkich nas przeżyjesz, pogrzebiesz i piechotą powracać będziesz ze cmentarza, to się sierdzisz i wierzyć nie chcesz. Końskie zdrowie i basta. Łapa (zwykłe jego wyrażenie gdy wyciągając swoją rękę brał moją do pocałowania).

Lucjan Rydel

Odpisując ten list, muszę wyjaśnić, dlaczego nazywał on mnie lekkomyślną dziewczyną. Oto dlatego, że gdy raz zostawił on klucz od mojego przedpokoju w Bronowicach, a Konda zamknęła mnie w mieszkaniu, chciałam wychodzić oknem, co jako z parterowego mieszkania trudnem nie było, ale on od tego czasu nazywał mnie lekkomyślną dziewczyną.

\section{[s. 129] Piatek, 5 kwietnia}

Gdy kiedyś był tu młody Lutek po owies dla koni, opowiadał mi, że ojcu zmieniło się w tej chorobie usposobienie, że jest ciągle rozdrażniony, gniewa się o byle jaką drobnostkę, martwi zarówno o politykę, jak i o domowe sprawy i czasem lubo jest ogromnie osłabiony i miewa gorączki, spuszcza nogi z łóżka i chce gdzieś iść. Naturalnie że do tych niepokojów i irytacji jest dosyć powodów, gdy sobie pomyśli, że opuszcza wykłady płatne na godziny, a tem samem jest pozbawionym dochodów, tak obecnie potrzebnych. $[\ldots]^{\mathrm{a}}$

a Opuszczono dalszy ciag rozważań A. Czechówny nad przyczynami irytacji i niezadowolenia L. Rydla

${ }^{76}$ Izabela z Czechów $1^{\circ}$ v. Lisowiecka, $2^{\circ}$ v. Dzianottowa (1842-1877), młodsza siostra Aleksandry.

${ }^{77}$ Bronisława z Bielańskich $1^{\circ}$ v. Dzianottowa (ur. 1881) i Kazimierz Promińscy. Z pierwszym mężem Janem Kantym Dzianottem (1865-1915) Bronisława miała czworo dzieci: Andrzeja (Jędrusia) (ur. 1901), Juliana (ur. 1903), Emilię zw. Milutką (1905-1916) i najmłodszego Jana Kantego (ur. 1909). 


\section{[s. 133] Sobota, 6 kwietnia}

Doprawdy, ale takich czasów jak obecne jeszcze nie przeżywałam. Choroba Lucjana dotyka mnie głęboko, a tu temczasem Klocia, przyszedłszy do mnie dzisiaj, przynosi mi same złe wiadomości.

Matka Brońci Promińskiej, Bielańska, pojechawszy do Opawy, do drugiej córki Rudzińskiej $^{78}$, dostaje zapalenia płuc i jest śmiertelnie, bez nadziei chora. Telegrafowano do Promińskich i oni oboje zaraz pojechali, zostawiwszy dzieci pod opieką Kloci. Druga siostra Brońci Stanisławowa Noëlowa, u których to byłam na wilii, chciała także jechać do matki, ale lekarz nie pozwolił, mówiąc, że jej mąż Stanisław ${ }^{79}$ [s. 134] ma także początki zapalenia płuc, więc nie radzi żonie odjeżdżać. [... $]^{\mathrm{a}}$

\section{[s. 135] [...] Poniedziałek, 8 kwietnia}

Wszystko skończone! Dziś przed godziną trzecią umarł Lucjan. Podobno śmierć miał spokojną i bez boleści.

Umarła także Bielańska. Jestem tak przybita, że więcej pisać nie mogę.

Wczoraj odprawiłam za niego drogę krzyżową, a dzisiaj wysłuchałam mszy św. i przyjęłam komunię św. Boże! Pociesz nas wszystkich, ale szczególniej biedną matkę! Przecież to już piąty, ostatni syn! Okropność!

\section{[s. 136] Wtorek, 9 kwietnia}

Wczoraj wieczorem przyszła do mnie Jadwisia Rydlowa z Langową ${ }^{80}$. - Obie były dla mnie bardzo serdeczne, a ponieważ opowiadały jak on [L. Rydel] był dobrym i poczciwym dla wszystkich w domu, a zarazem Jadwisia unosiła się, jak dobrą dla niego i pełną poświęcenia była owa pielęgniarka, Żydówka Pepa Singerówna ${ }^{81}$, wszystko to więc razem wzięte uspokoiło zupełnie moje sumienie pod względem obawy, czy ja też w ich pożycie nie wniosłam jakiegoś rozstroju. Pomimo mojego smutku roześmiałam się z mojego przypuszczenia, za co najserdeczniej podziękowałam Bogu.

Jadwisia bardzo ładnie i dobrze [s. 137] wygląda, widocznie więc Lucjan, przyjmując pomoc tylu pielęgniarek, oszczędzał pod każdym względem Jadwigę, toteż nie widać po niej utrudzenia.

a Opuszczono fragment, w którym A. Czechówna martwi się o zdrowie H. Kowalskiego i swej stużacej Kunegundy

${ }^{78}$ Emilia z Komorowskich Bielańska (ok. 1850-1918), wdowa po Bronisławie (1844-1883). Wspomniana tu Maria z Bielańskich Rudzińska, żona Ferdynanda, była jedną z jej córek.

${ }^{79}$ Stanisław Noël był żonaty z Wandą z Bielańskich (córką Emilii i Bronisława), trzecią siostrą Bronisławy z Bielańskich $1^{\circ}$ v. Dzianottowej, $2^{\circ}$ v. Promińskiej, wówczas żony Kazimierza.

${ }^{80}$ Helena Langie z Rydlów (1874-1920), siostra Lucjana jun., wdowa po Adamie (1864-1907), lekarzu-okuliście, z którym miała syna Antoniego oraz córki Marię i Annę.

${ }^{81}$ Pepa, właśc. Perel Singer (1881-1955), najmłodsza z pięciorga dzieci bronowickiego karczmarza Hirsza Singera i Debory z Unterweiserów. Mieszkając w Bronowicach, miała kontakt z młodopolskimi artystami i literatami z Krakowa. Zaproszona na wesele Rydla z Mikołajczykówną, była pierwowzorem postaci Racheli z Wesela Stanisława Wyspiańskiego. Po ukończeniu w 1914 r. kursu pielęgniarskiego pracowała w szpitalach wojskowych, a po zakończeniu wojny jako przełożona pielęgniarek w Szpitalu Wojskowym w Bronowicach. W październiku 1919 r. przyjęła sakrament chrztu, obierając imię Józefa (chrzestnymi byli Włodzimierz Tetmajer i Anna Rydlówna), zgodnie ze złożonym ślubowaniem, iż dokona tego, gdy Polska odzyska niepodległość. 
Podobno najwięcej z nich desperuje syn Lutek, który nawet do Krakowa nie przyjechał. Pogrzeb będzie okazały i kosztem miasta.

Wtorek, wieczór

$[\ldots]^{\mathrm{a}}$

[s. 140] [...] Piatek, 12 kwietnia

$[\ldots]^{\mathrm{b}}$

\section{[s. 141] [...] Piątek wieczór}

Muszę tu jeszcze choć w kilku słowach wspomnieć, że przy zwłokach w Bronowicach była rano we środę msza św., przy której cała rodzina się komunikowała, poczem pochód ruszył do Krakowa, prowadzony przez biskupa Nowaka ${ }^{82}$, który całą tę drogę odbył piechotą, jak również i wszyscy księża. - O dalszych uroczystościach pogrzebowych nic więcej nie piszę, zamieszczając [s. 142] sprawozdanie z gazet na końcu pamiętnika ${ }^{83}$.

\section{Piątek, 19 kwietnia}

Ażeby już w zupełności uspokoić moje sumienie, iż ja w najmniejszej nawet cząstce nie ukrzywdziłam Jadwisię i nie wniosłam do ich małżeńskiego pożycia jakiegokolwiek bądź rozdźwięku, może posłużyć list Lucjana, który zostawiony był Hani jeszcze przed operacją na wypadek jego śmierci. Ponieważ operacja odbyła się szczęśliwie, list został otwartym dopiero teraz, po pogrzebie i zawierał następujące słowa:

„Na wypadek śmierci mojej stwierdzam, że do ostatniego tchnienia wielbiłem Boga, Stworzyciela i Odkupiciela mojego, że Mu [s. 143] dzięki czynię za wszystko, za życie i śmierć, i że jemu ofiaruję moje pragnienie życia, mój żal, a Jego opiece oddaję co mam najdroższego na ziemi: Żonę - matkę - dzieci i siostry. Matkę moją żegnam na krótko, zobaczymy się wnet w chwale wiecznej, na łonie Bożem. Żonie mojej, najlepszej, najcierpliwszej, najdroższej, dziękuję za nieprzerwane szczęście, jakie mi dała od dnia ślubu. - Niech pamięta, że ma żyć dla dzieci i niech bierze wzór z matki mojej. Dzieciom błogosławię z całej duszy, za grobem czuwać nad niemi będę i Boga prosić o ich dobro ziemskie i wieczne. Niechaj matkę swoją czczą,

a Opuszczono fragment, w którym A. Czechówna rozważa swój stosunek do L. Rydla, którego bardzo ceniła za wiedzę, umiejętność jej przekazywania, pracowitość. Ma też świadomość, że bardzo się do niego przywiązała, stąd jego śmierć jest dla niej szczególnie bolesna

${ }^{\mathrm{b}}$ Opuszczono fragment rozważań A. Czechówny po lekturze Żywotów Świętych P. Skargi

82 Anatol Nowak (1862-1933), studiował teologię na UJ (1881-1885). Święcenia kapłańskie przyjął 5 lipca 1885 r., a w roku następnym został kapelanem kardynała Albina Dunajewskiego. Nominację na biskupa pomocniczego diecezji krakowskiej otrzymał 17 grudnia 1900 r., po śmierci bp. Jana Puzyny (8 września 1911 r.) sprawował rządy w diecezji jako wikariusz kapitulny, a po wyborze Adama Stefana Sapiehy na ordynariusza krakowskiego objął 6 marca 1912 r. urząd wikariusza generalnego i oficjała.

${ }^{83} \mathrm{Na}$ końcu tego tomu „Dziennika” (s. 404), obok wycinków prasowych z „Nowej Reformy” (zob. przyp. 24) A. Czechówna napisała: „Na pogrzebie nie byłam, gdyż brakło mi do tego i siły fizycznej i moralnej, ale słyszałam, że na cmentarzu były takie tłumy, że się ludzie po prostu dusili. Czy jednak nie skończy się to na czczej demonstracji, przyszłość okaże". 
niech ją pocieszają, niech Jej będą osłodą. [s. 144] Siostrom pożegnanie najczulsze, polecam im żonę, matkę i dzieci moje. Jeśli możliwe będzie, pragnę i zaklinam na wszystko, aby nasz kawałek ziemi w Bronowicach utrzymał się przy rodzinie mojej. Nie sprzedawać, chyba w ostateczności! - szkoda, że nie dożyję wolnej, zjednoczonej, niepodległej Polski. Za nią Bogu ofiaruję moją śmierć. O niej ostatnia moja myśl na ziemi!".

Powtarzam, że przeczytawszy ten list, zupełnie się uspokoiłam, nabywszy przeświadczenia, że jeśli mnie lubił i szukał mojego towarzystwa, to jedynie tylko i wyłącznie ze względów umysłowych i literackich. Mogę więc z całym spokojem cieszyć się temi wspomnieniami.

\section{[s. 145] Środa, 1 maja}

Jak dalece jestem obecnie złamaną i jak mi się już nic nie chce, może posłużyć następujący przykład.

W tę niedzielę o godzinie dwunastej było uroczyste posiedzenie w Uniwersytecie ku uczczeniu zmarłego księdza Pawlickiego ${ }^{84}$. Na posiedzeniu tem miał przemawiać Witold Rubczyński, Sinko ${ }^{85}$ i jeszcze jakiś profesor ${ }^{86}$. Ponieważ to posiedzenie było za biletami zapraszającemi ${ }^{87}$, Rubczyńska przysłała mi Klocię Kowalską z zapytaniem, czy bym z niemi pójść nie chciała. - Kiedy indziej chętnie byłabym na to przystała, boć przecież

${ }^{84}$ Ks. Stefan Pawlicki (1839-1916), zmartwychwstaniec, filozof. Studiował filologię klasyczną na Uniwersytecie we Wrocławiu (1858-1862), następnie był guwernerem Edwarda Aleksandra Raczyńskiego, by ponownie w 1864 r. podjąć studia, tym razem na Wydziale Filozoficznym. W 1865 r. uzyskał tytuł doktora filozofii, a w roku następnym nominację na docenta filozofii w Szkole Głównej w Warszawie. Pierwotnie obojętny wobec wiary, pod wpływem ks. Piotra Semenenki (1814-1886), współzałożyciela i generała Zgromadzenia Zmartwychwstańców, zbliżył się do katolicyzmu, wstąpił do zakonu (grudzień 1868, święcenia kapłańskie 30 marca 1872) i podjął studia teologiczne w Rzymie (1869-1873), a następnie sam był wykładowcą na uczelniach rzymskich. W 1882 r. objął katedrę filozofii na Wydziale Teologicznym UJ, a w 1892 katedrę filozofii na Wydziale Filozoficznym. Był (od 1886 r.) profesorem zwyczajnym teologii fundamentalnej i filozofii chrześcijańskiej, a w $1894 \mathrm{r}$. otrzymał nominację na profesora zwyczajnego filozofii. W 1910 r. przeszedł na emeryturę, ale nadal prowadził zajęcia. Miewał też wykłady na Wyższych Kursach dla Kobiet im. A. Baranieckiego i odczyty publiczne. Zmarł 28 kwietnia $1916 \mathrm{r}$.

${ }_{85}$ Tadeusz Sinko (1877-1966), filolog klasyczny. Studiował filologię klasyczną i polską na UJ (1896-1900). Jednym z jego wykładowców był ks. Stefan Pawlicki (historia filozofii antycznej), pod którego opieką napisał też rozprawę doktorską o Grzegorzu z Sanoka (październik 1900 r.). Potem pogłębiał swą wiedzę filologiczną w Berlinie, Bonn (1900-1901) i Monachium (1902-1903). W grudniu 1903 r. habilitował się na UJ. Krótko prowadził wykłady (1904/1905), po czym ponownie wyjechał za granicę (Paryż, Florencja, Wenecja, Mediolan, 1905-1907). Od września 1907 r. profesor na Uniwersytecie Lwowskim (do 1913), następnie na UJ. Po wybuchu I wojny światowej powołany do wojska, był komendantem ciężkiej baterii (Kraków, Przemyśl). Na początku 1916 r. wyreklamowany ze służby wojskowej, powrócił do pracy na uniwersytecie.

${ }^{86}$ Był to Wojciech Gielecki (1876-1957). Studiował na Wydziale Filozoficznym (1894-1901), m.in. u ks. S. Pawlickiego i Maurycego Straszewskiego. W 1904 r. uzyskał tytuł dr. filozofii (z wyróżnieniem), w 1907 r. podjął pracę w Bibliotece Jagiellońskiej, gdzie jako kustosz pracował 50 lat.

${ }^{87} \mathrm{~W}$ drugą rocznicę śmierci ks. S. Pawlickiego Krakowskie Towarzystwo Filozoficzne urządziło w niedzielę 28 kwietnia 1918 r. uroczyste posiedzenie w auli UJ, a w poniedziałek 29 kwietnia 
ksiądz [s. 146] Pawlicki należał do moich ulubionych pisarzy i prawie wszystkie jego prace znałam, a gdy do tego jeszcze i Witold miał przemawiać, było to więc nawet nie bardzo grzecznie z mojej strony, że biletu nie przyjęłam. - Tymczasem Witold przekonał mnie, jak szlachetnym jest człowiekiem, gdyż zaraz tego samego dnia przyszedł do mnie po południu, mówił, że mi się wcale nie dziwi, że mi się obecnie nigdzie pójść nie chce, a kiedy zaczęłam mu opowiadać o Lucjanie i rozpłakałam się, on także się rozpłakał i tak się zakończyła nasza rozmowa, ale która przekonała mnie, że mam w Witoldzie bardzo mi życzliwego przyjaciela.

\section{[s. 147] Wtorek, 7 maja}

Już to dobrze mówi francuskie przysłowie, że „,malheur ne vient jamais seul”"88. Jeszcze nie ochłonęłam po śmierci Lucjana, a już grozi mi znów drugie.

Gdy weszłam rano do kuchni, zastałam Kondę jęczącą z bólu, myślałam że to coś żołądkowego, tymczasem kiedy poszłam prosić Henryka Kowalskiego, ażeby ją odwiedził, ten znalazł jakąś narość w okolicy ślepej kiszki, która według niego powinna być zaraz operowana. On poszedł do kliniki, a ja jakby uderzona w głowę [s. 148] jakąś pałką zostałam bezradna w domu. - Co się ze mną stanie, gdy Konda pójdzie do kliniki, a co gorzej gdy umrze, nie mogę na razie pomyśleć i tylko trzeba mi się modlić, modlić i jeszcze raz modlić.

\section{Czwartek, 16 maja}

Ponieważ z powodu choroby Kondzi jestem zapraszana na obiady do Promińskich, a znów na kolacje do Tadziów Kremerów, którzy mi również okazują wiele życzliwości i przyjaźni, gdy więc tylko na krótką chwilę jestem w domu, nie mam więc kiedy zaglądać do Ciebie, i dlatego tylko w krótkości napiszę, że Konda powróciła ze szpitala, [s. 149] a właściwie uciekła stamtąd, mówiąc, że tam ani jeść, ani spać nie mogła, więc przyszła do mnie, ale w takim stanie, że się aż przelękłam i w ogóle widzę, że z niej już żadnej pociechy nie będę miała, a obecnie mam tylko kłopot, bo nie tylko że mnie już nic zrobić nie może, ale jeszcze o niej myśleć muszę.

W ogóle powiem, że ze śmiercią Lucjana skończyła się dla mnie wszelka pomyślność, wszelkie przyjemne chwile, a spotykają mnie tylko same przykrości, udręczenia, przy tem i zdrowie podupada, noga boli, jednem słowem wszystko złe wali się na mnie.

\section{[s. 150] Sobota, 18 maja}

Wszystkie biedy walą się na mnie. - Gdy poszłam dziś rano do kościoła, dostałam tak szalonych boleści, że o mało nie zemdlałam i przyjąwszy tylko komunię św. i to z wielkim strachem, gdyż mnie przy tem i nudzić zaczynało, powróciłam, zataczając się do domu. Nie wiedząc, co robić, posłałam stróża po Henryka. Przyszedł zaraz, ale właściwie nic mi nie poradził. Powiedział, że byłyby wskazane kąpiele, picie wody, ale w mojem położeniu nie jest to możliwe. Trzeba więc cierpieć i czekać cierpliwie końca.

odprawiona została msza święta w jego intencji w kościele akademickim św. Anny („Czas” nr 195 z 28 kwietnia 1918 r., s. 1; nr 196 z 29 kwietnia 1918 r., s. 2).

${ }^{88}$ Un malheur ne vient jamais seul - przysłowie francuskie: nieszczęścia chodzą parami; dosł. nieszczęście nigdy nie przychodzi samo. 


\section{[s. 151] Czwartek, 30 maja}

Wczoraj Rydlowa, matka Lucjana, pojechała do Dołuszyc, do Mikołajowej Rydlowej ${ }^{89}$, odprowadzona przez Tadzia Kremera. W ostatnich czasach widziałam się także z Jadwigą Rydlową, z córką Heleną i z ich dobrego wyglądu i wesołego usposobienia widzę, że śmierć Lucjana nie zrobiła na nikim tak potężnego wrażenia jak na mnie. Do tego przyczynia się zapewnie [!] i to, że są oni bardzo dobrze zaopatrzeni, składki idą obficie ${ }^{90}$, dworek w Bronowicach bardzo korzystnie wynajęty, jednem słowem będą oni może teraz [s. 152] stać lepiej niż dawniej.

Nie mogę tego powiedzieć o sobie, gdyż co się tyczy mojego utrzymania, to i tutaj zmiany wcale niewesołe. - Lecz zamiast pisać jeremiady, wolę zanotować, iż kupiwszy sobie dziwnym trafem, niedarowany mi przez Lucjana Rydla jego Bodenheim, przeczytałam go uważnie, jako w maju miesiącu jemu poświęconym i doszłam do przekonania, że jeżeli ten dramat nie miał takiego powodzenia jak inne jego utwory, to tylko dlatego, że scena z duchami była, przynajmniej na naszej scenie źle przedstawiona, lubo zawsze wolę inne jego utwory.

\section{[s. 153] Wtorek, 4 czerwca}

$\mathrm{Na}$ wstępie do tego miesiąca zakończyłam czytanie poświęcone pamięci Józefa Kremera, zakończywszy zarazem jego Podróż do Włoch, która mi tyle lat zajęła. Zakończenie tej Podróży zbiegło się u mnie z zamknięciem karty mojego życia, bo że ta karta jest już zamknięta, i że odtąd będzie to tylko nędzna wegetacja oczekująca śmierci, to więcej jak pewna [!]. Właściwie powinnam już zakończyć i ten pamiętnik, że jednak i pisanie takowego, i odczytywanie go, sprawia mi [s. 154] niewypowiedzianą przyjemność, nie chcę się jej pozbawiać.

A teraz trzeba mi się zapytać, przy jakim ustępie mam się z tobą pożegnać drogi mój przyjacielu [J. Kremer]. Oto pożegnajmy się przy Dioskurach, tych braciach bliźniętach zdobiących plac Kwirynalski. [... $]^{\mathrm{a}}$

a Opuszczono przytoczone przez A. Czechównę stwierdzenie Józefa Kremera, że każdy człowiek ma w sobie dwie natury: jedna dobra, prowadzaca do nieśmiertelności i druga ułomna, zła, ciagnaca go ku mrokowi. Dalej A. Czechówna dochodzi do wniosku, że i w jej stosunku do J. Kremera i do jego wnuka L. Rydla odnaleźć można takie przeciwstawne odniesienia

${ }^{89}$ Mikołaj Rydel (1874-1917), syn Romana (1835-1899) i Sabiny z Marynowskich, zmarł 2 grudnia 1917 r. Ukończywszy szkołę rolniczą w Dublanach, gospodarzył najpierw w Nizinach. Po ich sprzedaży nabył majątek w Dołuszycach (obecnie osiedle w granicach miasta Bochni). Ożenił się z Jadwigą z Łastowieckich (1880-1948), z którą miał trzech synów: Andrzeja (1906-1939), Jana i Romana Jerzego.

${ }^{90}$ Po śmierci L. Rydla z inicjatywy prof. Józefa Rostafińskiego (1850-1928), prof. botaniki i historii nauk przyrodniczych UJ, prywatnie jego wielkiego przyjaciela, pod przewodnictwem prezydenta miasta Jana Kantego Federowicza, powstał „Komitet ku uczczeniu pamięci śp. Lucjana Rydla”, w którym Rostafiński pełnił funkcję skarbnika. 9 i 10 kwietnia 1918 r. ukazał się w „Czasie” apel do narodu polskiego nawołujący m.in. do wsparcia rodziny i dzieci zmarłego poety. Składki można było przesyłać do redakcji krakowskich pism codziennych („Czasu”, „Nowej Reformy”) lub bezpośrednio do skarbnika komitetu. Na odezwę tę odpowiedziało wielu obywateli. 


\section{[s. 156] [...] Poniedziałek, 10 czerwca}

Za kilka dni wyjeżdżam do Świdnika, nim to jednak nastąpi, wzięłam jeszcze do ręki Poezje Rydla, nie chcąc się w tym roku z nim rozstawać, przy jego sarkastycznym Bodenheimie. Jego mitologie i przekłady z Horacego mniej mnie zadowolniły [!], [s. 157] ale co mi się naprawdę podobało, to jego poetyczne opisy z Grecji. Malują one najlepiej, jakie wrażenie zrobiły na nim Ateny, a szczególniej Akropolis, gdy powiada:

Ta kolumnada i za nią ta ściana

Te jej marmury białe i złotawe

Wydały mi się jako morska piana,

Która stężała tam na skalnym szczycie

I otworzyła triumfalne wrota

Aby uczynić przejście Afrodycie

Gdzie się wynurzy promienna i złota

Z głębiny słonej... [... $]^{\mathrm{a}}$

[s. 159] [...] I powiedzieć, że ja to wszystko widzieć mogłam, i to widzieć w jego towarzystwie - a nie widziałam.

\section{[s. 160] Środa, 12 czerwca}

Wczoraj przyjechała Julcia Walterowa po Marysię i po mnie. Dzielna z niej kobieta, ale jak na mnie za wielka pani. Stanęła u mnie z Marysią, ale czy ta ostatnia będzie u mnie od wakacji, jeszcze nie wiem. Ona chciałaby koniecznie, abym zmieniła służącą, ponieważ jednak Kondzi jest trochę lepiej i dr Buzdygan, który ją ma w kuracji, ma nadzieję, że będzie znacznie lepiej, nie mam więc serca oddalać ją na taką drożyznę. W piątek wyjeżdżamy końmi, a więc do widzenia w Świdniku.

\section{[s. 161] Świdnik, czwartek, 20 czerwca}

Jestem na koniec w Świdniku. Zanim jednak tu się dostałam, użyłam dosyć trudów i niewygód. Najgorsze było pakowanie, a gdy Konda w niczem mi pomóc nie mogła, było to na moje stare lata ciężkie zadanie i jakże zazdrościłam Rydlowej takiej Hani, która jej wszystko ułatwi, wszystko zapakuje i ona potrzebuje tylko wsiąść do powozu, i jechać sobie jakby na spacer, a kiedy jedzie koleją, to jej nawet wyrabiają oddzielny przedział, podczas kiedy ja muszę się o wszystko troszczyć sama.

Tym razem Julcia wiele mi [s. 162] ułatwiła, gdy jechałyśmy końmi.

Najpierwej zajechałyśmy do Bilczyc, do Kopaczyńskich, którzy to mieli połamane nogi jadąc koleją i tyle miesięcy spędzili w Krakowie w sanatorium. Obecnie chodzą już, ale z laskami i nogi jeszcze ich bolą. Bilczyce bardzo ładne, ogród ślicznie położony, ale już najładniejsze ich dwie córeczki, miłe i grzeczne dziewczątka ${ }^{91}$. Stamtąd podążyłyśmy do Świdnika, ale że jest on oddalonym przeszło o 10 mil, byłam więc dosyć utrudzona, zwłaszcza że popasu nie było innego, tylko w polu, a do tego spotkała nas burza. Mimo tych

${ }^{a}$ Opuszczono dalszy ciag wiersza Akropol Ateński. Propylaje, zamieszczonego w trzecim wydaniu (,,znacznie pomnożonym”) tomiku Poezje, Kraków 1909, s. 210-211. Podróż do Grecji i Turcji L. Rydel odbyt wiosna 1907 r. i bardzo namawiat A. Czechównę do wspólnego wyjazdu

${ }^{91}$ Michalina (ur. 1915) i Zofia (ur. 1916). 
wszystkich niewygód zajechałyśmy szczęśliwie, a że mam mój ulubiony pokój, z którego [s. 163] szczęśliwie wyniosły się zupełnie szczury, które w zeszłym roku tak mnie trapiły, mam więc nadzieję, że będzie mi tu dobrze, i że może przyjdę powoli do siebie, gdyż w ostatnich czasach było już ze mną bardzo niedobrze.

\section{Poniedziałek, 24 czerwca}

$[\ldots]^{a}[$ s. 164] [...] Ale teraz piszmy o czem innem. - „Lubo poznałaś innych gienialnych [!] pisarzy i poetów, to jednak ty ze swojem usposobieniem powrócisz się do Schillera, gdyż on najwięcej odpowiada twojej duszy". - Słowa te, powiedziane na ostatnim obiedzie przez Lucjana, spełniły się najzupełniej i obecnie muszę się jeszcze cokolwiek zastanowić nad jego dramatami, które ostatniemi czasy przeczytałam, to jest Die beiden Piccolomini i Wallenstein's Tod. Według mnie w całej literaturze // [s. 165] nie ma równie szlachetnych i podniosłych kochanków jak Max i Tekla. [...] $]^{\mathrm{b}}$

[s. 166] [...] Co się zaś tyczy całej tragedii, to chcąc się przekonać, jak też Schiller obszedł się tutaj z historią i czy od niej nie odstąpił, przewertowałam wojnę trzydziestoletnią i widzę, że o ile poeta może być zgodnym z historią, to Schiller jest nim tutaj i charakter Wallensteina jest tutaj rzeczywiście historycznie skreślonym. //

\section{[s. 167] Poniedziałek, 8 lipca}

A teraz pomówmy o drugim utworze Schillera, który właśnie skończyłam, to jest o jego Dziewicy Orleańskiej.

Pisząc, że wzięłam tu sobie, jakby w testamencie po Lucjanie, Żywoty Świętych Skargi i Schillera, wydaje się to być pewną anomalią, gdyż Skarga i protestant nie zdają się mieć ze sobą jakiejkolwiek spójni, a jednak tak nie jest, bo co tam daje wiara, to tu stwarza szlachetny charakter i szukanie ideału. $[\ldots]^{\mathrm{c}}$

[s. 169] [...] O! Święta Joanno! Gdy dziś mogę wraz z całym katolickim Kościołem modlić się do Ciebie, polecam Ci duszę tego protestanta [Friedricha Schillera], ale modląc się za tego szlachetnego Niemca, usłysz także moje modlitwy za biedną obecnie Francję, ale i moją Polskę i zeszlij aniołów do pobicia jego niecnych i nikczemnych rodaków [Niemców].

\section{[s. 170] Środa, 17 lipca}

Już jest ułożone, że Klocia będzie mieszkać ze mną, ponieważ zaś jest ona młodszą i energiczniejszą ode mnie, a tem samem pewnie prędzej da sobie radę z tak trudną obecnie

\footnotetext{
a Opuszczono fragment informujący o wyjeździe Julii Walter z córka Marysią do Krynicy i przyjeździe Klotyldy Kowalskiej do Świdnika

${ }^{\text {b } O p u s z c z o n o ~ d a l s z e ~ r o z w a z ̇ a n i a ~ A . ~ C z e c h o ́ w n y ~ p o ~ p r z e c z y t a n i u ~ d w o ́ c h ~ c z e ̨ s ́ c i ~ t r y l o g i i ~ d r a m a-~}$ tycznej autorstwa Friedricha Schillera, Wallenstein. Poemat dramatyczny (Obóz Wallensteina, Dwaj Piccolomini, Śmierć Wallensteina). Wedtug niej uczucie Maxa i Tekli miało głęboka podstawę moralna w odróżnieniu od mitości Romea i Julii opierającej się tylko na powierzchowności

' Opuszczono fragment, $w$ którym A. Czechówna porównuje sposób przedstawienia Joanny d'Arc przez Voltaire'a, Szekspira i Schillera. W odróżnieniu od pierwszych dwóch, którzy uznają bohaterkę za ulicznicę i podła istotę, ten ostatni rozumie ja, $i$ widzi $w$ niej osobę święta
} 
aprowizacją, dlatego ja ustępuję jej wszelkie prawa gospodyni i pragnę, żeby mi się zdawało, że jestem w pensjonacie.

Największa trudność była z Kondą, gdyż zarówno Klocia, jak i Jula chciały koniecznie starać się o inną służącą, gdy jednakowoż Dorcia ${ }^{92} \mathrm{w}$ jej imieniu napisała tutaj, że Konda jest zdrowa, że robi porządki, i że nie przypuszcza, abym na zimę, i to jeszcze wśród takiej drożyzny miała ją oddalić, wobec więc tego Klocia [s. 171] zmiękła i zatrzymuje ją nadal, co i mnie także bardzo dogadza. Z tego wszystkiego okazuje się, że dr Buzdygan, do którego ją posłałam, jest bardzo dobrym doktorem, a przeciwnie Henryk lubo tak zarozumiały w swoją wiedzę, absolutnie się na jej chorobie nie poznał.

Julcia z Marysią są jeszcze w Krynicy, ale myślę że niedługo powrócą, gdyż był tu grad dość duży, który uszkodził zboża, a tem samem myślę, że Julcia będzie chciała przyjechać, ażeby być obecną przy komisji.

O sobie cóż napiszę? Jest mi tu dobrze, a że umiem wystarczać sama sobie, więc dnie schodzą mi tu bardzo prędko, chociaż właściwie bez towarzystwa, gdyż stara Walterowa jest dosyć nudna, a Klocia zajęta gospodarstwem.

\section{[s. 172] Środa, 24 lipca}

[... $]^{a}$ [s. 174] [...] Lecz i w rodzinie Rydlów także niewesoło. - Było mi przykro, że od nich nie miałam dłuższy czas wiadomości, temczasem kiedyś odebrałam od Rydlowej list bardzo smutny, że Langowa przeszła zapalenie płuc, że lekarz wysłał ją do sanatorium dr Dłuskiego w Zakopanem ${ }^{93}$, że Hani zrobił się znów jakiś absces ${ }^{94}$ na policzku, który musiał być przecinanym i musi jeździć do opatrunków, biedna zaś Helenka [Rydlowa] pisze, że ona nie wie nawet, czy to nie jest coś groźnego i czy i z Langową nie jest źle, gdyż ją zawsze oszukują i wskutek [s. 175] tego żyje ona w ciągłej trwodze. W Bronowicach zdrowi, ale Helenka [Rydlówna] ma poprawkę z matematyki, gdyż według tego jak pisze Rydlowa, jest z niej wielki leniuszek.

I tak wszędzie zmartwienia i kłopoty.

${ }^{a}$ Opuszczono fragment, w którym A. Czechówna pisze o problemach zdrowotnych Stasi Noëlowej, która poroniła, w wyniku czego jest w złej formie fizycznej i psychicznej. Z tego powodu konieczny jest przyjazd do niej Julii Walterowej. Wiadomość tę przekazat przyjaciel rodziny Paszkowski

${ }_{92}$ Prawdopodobnie Teodora Zoner (Zonner), siostra Natalii Bańkowskiej, zmarłej w 1917 r. właścicielki kamienicy przy ul. Długiej 35, w której A. Czechówna mieszkała.

${ }^{93}$ Kazimierz Dłuski (1855-1930), lekarz i społecznik. Od lat młodzieńczych związany z ruchem socjalistycznym. W 1878 r. udał się na emigrację, najpierw do Genewy, potem do Paryża, gdzie ukończył studia (nauki polityczne i medycynę) i podjął praktykę lekarską. W 1900 r. z żoną Bronisławą, również lekarką (starszą siostrą Marii Skłodowskiej-Curie) zamieszkał w Zakopanem, gdzie w 1902 r. otworzył nowoczesne sanatorium dla ludzi z chorobami płuc, którym kierował przez 16 lat. Był również jednym z założycieli Tatrzańskiego Ochotniczego Pogotowia Ratunkowego (TOPR) (i pierwszym prezesem) oraz Muzeum Tatrzańskiego im. Tytusa Chałubińskiego. W $1919 \mathrm{r}$. mianowany został obok Romana Dmowskiego delegatem Polski na konferencję pokojową w Paryżu i w tym też roku przeniósł się do Warszawy.

${ }^{94}$ Absces - (med.) ropień, wrzód. 
Poniedziałek, 29 lipca

Ponieważ Julcia jeszcze nie powróciła z Komborni, o Stasi więc nic więcej nie wiemy, dlatego dzisiaj wolę się znów powrócić do Schillera. - Jeżeli w Dziewicy Orleańskiej jego katolickie przekonania silnie się zadokumentowały, to w Marii Stuart, którą niedawno skończyłam, są one może jeszcze widoczniejsze. [... $]^{\mathrm{a}}$

[s. 178] [...] I jest to rzecz dziwna, że jak przy Dziewicy Orleańskiej Schiller wyprzedza wyrok Kościoła, tak znów przy Marii Stuart wyprzedza on wyrok historii, gdyż właśnie najnowsze badania historyczne, jakie nam przyniósł niedawno Stanisław // [s. 177] Smol$\mathrm{ka}^{95}$, zgadzają się zupełnie z poglądami Schillera.

Ale nie samą tak idealną literaturą zajmuję się tutaj, gdyż równocześnie przeczytałam tu także Hrabinę Cosel i ministra Brühla z czasów saskich Kraszewskiego ${ }^{96}$. [... $]^{\mathrm{b}}$

\section{[s. 178] [...] Sobota, 3 sierpnia}

Obecnie muszę słów kilka poświęcić Marysi Walterównie. Otóż powiem, iż mimo tego, że dziewczyna ta powszechnie się podoba, i dla mnie okazuje wiele przywiązania, to jednak obudza ona we mnie wiele obaw pod względem jej przyszłości. Najprzód ma ona zdrowie bardzo delikatne i mimo Krynicy często jej coś brakuje. Przy tem jest ona szalenie // [s. 179] nerwowa i może wskutek tego nie może ani jednego dnia posiedzieć w domu. Ciągle chciałaby gdzieś jechać, bawić się i przede wszystkiem stroić. Ta jej mania strojenia się jest według mnie bardzo niebezpieczna i zupełnie nie licuje z grozą obecnego położenia. $[\ldots]^{\mathrm{c}}$

${ }^{a}$ Opuszczono fragment, w którym A. Czechówna za F. Schillerem zastanawia się, czy Maria Stuart swoim żalem za wcześniejsze postępki nie zastużyła jednak na miano świętej

${ }^{\mathrm{b}}$ Opuszczono fragment, $w$ którym A. Czechówna zastanawia się nad zepsuciem panujacym w czasach saskich i równocześnie z przykrościa stwierdza, że i obecnie obyczaje ludności wszystkich sfer pozostawiaja wiele do życzenia

c Opuszczono dalsze rozważania A. Czechówny o Marysi Walterównie, jej wielkim upodobaniu do strojenia się i zupetnym braku zainteresowania gospodarstwem. Opuszczono także informacje od Julii Walterowej o stanie zdrowia jej siostry Stanisławy Noëlowej

${ }^{95}$ Stanisław Smolka (1854-1924), historyk, publicysta. Studiował we Lwowie (1870/71) i w Getyndze (1871-1873), gdzie w 1873 r. uzyskał tytuł doktora. Habilitował się na UJ (1875). W $1876 \mathrm{r}$. objął na UJ katedrę historii Austrii, w 1880 r. otrzymał profesurę zwyczajną, a w 1883 r., po śmierci Józefa Szujskiego, katedrę historii Polski. Świetny mediewista (autor m.in. pracy Mieszko Stary i jego wiek, Warszawa 1881), z czasem zainteresował się też okresem nowożytnym. Wykształcił wielu znakomitych historyków. Aktywnie działał w Akademii Umiejętności, m.in. był inicjatorem ekspedycji badawczych do Archiwum Watykańskiego (tzw. Teki rzymskie). Był też dyrektorem Archiwum Krajowego Aktów Grodzkich i Ziemskich w Krakowie (1908-1919) i Muzeum Czartoryskich w Krakowie (1912-1917). Po wybuchu I wojny światowej stał się gorącym zwolennikiem Legionów. W Szkicach historycznych (Seria 2, Warszawa 1883, Gebethner i Wolff) opublikował rozprawę pt. Maria Stuart. Winna czy nie winna (s. 283-302).

${ }^{96}$ Hrabina Cosel (1874) i Brühl (1875) stanowią dwa pierwsze tomy napisanego przez Józefa Ignacego Kraszewskiego cyklu powieściowego Trylogia saska. 


\section{[s. 182] [...] Środa, 7 sierpnia}

Obecnie muszę znów poświęcić kilka słów Schillerowi, przeczytawszy jego Die Braut von Messina ${ }^{97}$. Spotykałam się ze zdaniem nawet u Lucjana, że jest to utwór słaby i chybiony. Nie powiedziałabym tego. $[\ldots]^{\mathrm{a}}$

\section{[s. 185] [...] Poniedziałek, 12 sierpnia}

Straszne mamy lato! Nie dość, że wojna nas gnębi, ale i sama przyroda zdaje się znęcać nad nami. - Blisko od dwóch tygodni ciągle prawie leje. Wszystkie górskie rzeczki wezbrały, popsuły drogi, tak iż np. do Łukowicy, gdzie jest kościół, nie będzie się można dostać, aż chyba kiedy w jesieni, gdy droga będzie naprawiona. Ale to jest jeszcze niczem wobec strat materialnych. - Całe łany zboża niedawno pożętego woda albo zabrała, a jeżeli jest w kopach, to te kopy rosną, że aż się zielenią, // [s. 186] jednem słowem straty olbrzymie i sama Julcia jest poszkodowana z pewnością więcej jak na 20 tysięcy koron. Jest też ona bardzo przybita, widząc jak jej całoroczna praca idzie na marne. Tylko Marysia nic sobie z tego nie robi i jeździ sobie patrzeć na wodę jak na ciekawe widowisko. Co dziwniejsza, to nie rachując się wcale z grozą położenia i z tem, że obecnie wyżywienie kogoś, nawet na wsi, pociąga za sobą wielkie koszta, zaprasza sobie, wcale się matki o pozwolenie nie pytając, swoje koleżanki na wakacje. $[\ldots]^{\mathrm{b}}$

[s. 187] [...] Lecz poznałam tu także i sympatyczną osobistość, jest nią pan Władysław Chwalibogowski, brat tutejszej sąsiadki Reklewskiej z Rogów ${ }^{98}$. Jest on porucznikiem w armii austriackiej. [s. 188] Najprzód był na froncie rosyjskim, ostatniemi czasy na włoskim, gdzie tak się zdenerwował i zapadł na zdrowiu, iż musiał wziąć urlop i dostał się tutaj do szpitala, ale ponieważ nie jest obłożnie chorym, a przy tem w szpitalu nie mają co jeść, więc przeważnie siedzi w Rogach i razem z Reklewskiemi nawiedza Świdnik.

Opowiadał on nam różne ciekawe szczegóły o wojnie, o jej okropnościach, a ponieważ jest bardzo miłym chłopcem, uważam więc, że się panienkom podoba, a jemu, jak mi się zdaje, podoba się najwięcej Narolska, przystojna brunetka. Mnie nauczył okszena ${ }^{99}$, odmianę bridge’a i podobno chwalił mnie, że jestem bardzo przyjemną staruszką, z którą grałby chętnie i przez całą noc w karty.

\section{[s. 189] Wtorek, 20 sierpnia}

Coraz większe klęski! Wszystkie rzeki w Galicji wylały, a tu ciągle nie ma pogody i żaden dzień nie przechodzi bez ulewnego deszczu. Przy tem zimno jak w jesieni,

${ }^{a}$ Opuszczono dalszy ciag oceny A. Czechówny tego utworu, wedlug której w porównaniu z innymi dziełami Schillera jest on pod względem dramatycznym słabszy, ale przewyższa je wszystkie swoim pięknym, petnym poezji językiem

b Opuszczono fragment opisujący koleżanki, które odwiedzity Marysię Walterównę podczas wakacji

${ }^{97}$ Dramat wierszem Oblubienica z Messyny, napisany w 1803 r.

${ }^{98}$ Władysław Chwalibogowski był bratem ciotecznym Janiny Reklewskiej (zob. dalej), której matką była Władysława Jadwiga Chwalibogowska.

${ }^{99}$ Okszen (brydż licytowany, z ang. auction bridge) - gra karciana, wywodząca się z wcześniejszego wista, jeden z przodków współczesnego brydża. Okszen wprowadził do gry nowe elementy nieznane wcześniej w wiście - licytację okrężną, wysokość deklarowanego kontraktu i wykładanie kart na stolik przez dziadka. 
a w duszy smutek i rozpacz, widząc jak wszystkie plony w polu marnieją. Jeżeli kiedy, to teraz widzi się słabość i bezradność człowieka, bo niechże tu teraz i największy gieniusz [!] zaradzi złemu.

A teraz piszmy o czem innem. Czytając tu mój sąd wydany o Marysi, można by sądzić, że jest ona jako jedynaczka zepsutem dzieckiem, a jednak tak nie jest, gdyż nie jest ona wcale wyjątkiem i poznając inne młode panny widzę, że jest to prąd // [s. 190] wspólny całemu młodemu pokoleniu panien. - Od czasu emancypacji, to jest od czasu jak kobieta zaczęła sobie wyrabiać niezależne stanowisko, czy to przez uniwersytet, czy na innych polach, rozbudziło to w niej jakąś zarozumiałość, która sprawia, że lekceważą zdanie starszych kobiet, mając się od nas za mądrzejsze i stąd nie bardzo chcą przyjmować jakiekolwiek uwagi, i chcą żeby nie one do nas, ale przeciwnie, my do nich stosowałyśmy się we wszystkiem, i spełniały ich wolę. Być może, że w Marysi, jako w jedynaczce i to do tego bogatej, której wszystkie życzenia są zwykle spełnianemi, jest ta arbitralność i despotyczność może jeszcze więcej rozwinięta niż u innej, ale że jest // [s. 191] ona ogólną to pewna. W każdym razie widzę, że stało się bardzo dobrze, że nie będzie ona mieszkać u mnie i mam przekonanie, że z Klocią będzie mi daleko lepiej.

\section{Środa, 28 sierpnia}

Coraz lepiej widzę i czuję, jak wiele straciłam przez śmierć Lucjana, bo kiedy on tak lubił i cenił moje towarzystwo, a kiedy wyjechałam, to na każdą moją odezwę odpowiadał mi długiemi i tak serdecznemi listami, a obecnie wszystko się zmieniło. Myśląc, że może jego dzieci potrafią mi go choć w części zastąpić, napisałam do jego córki, ta jednak dopiero po kilku tygodniach odpisała mi w kilku słowach na karcie, ale tak zimnych i konwencjonalnych, [s. 192] iż widzę, że tutaj niewiele się mogę spodziewać. [...]

[s. 193] [...] Wobec tego widzę, że nie powinnam tutaj robić żadnych uwag, a więc piszmy lepiej o Schillerze. Przeczytałam tu także jego Wilhelma Tella. Utwór ten posiada według mnie mniej wartości poetycznej, niżeli inne jego utwory, ma jednak i on piękne i podniosłe sceny. $[\ldots]^{\mathrm{b}}$

[s. 194] [...] W końcu muszę tu zaznaczyć, że nie mając w moim pokoju wygodnego stołu do pisania, a nie lubiąc się rozpościerać w innych pokojach i biurkach, piszę tutaj gorzej i może niewyraźniej niżeli w Krakowie. //

\section{[s. 195] Wtorek, 3 września}

Wielkie zadanie stoi przed Julcią i jeżeli ona temu wszystkiemu podoła i wybrnie szczęśliwie, to powiem, że jest ona najdzielniejszą kobietą, jaką znam.

Nie dość, że prawie wszystko zboże porosło i zmarniało, tak że nawet do siewu nie ma, ale nadto wszystkie budynki się walą, nie wyłączając i dworu, który jest bardzo zdezelowany i prawie we wszystkich pokojach zacieka. Był tu już jeden budowniczy ze Sącza, który ma te wszystkie roboty prowadzić, ale jeżeli kiedy, to teraz // [s. 196] będą one kosztowne, wyniesą [!] pewnie kilkakroć sto tysięcy koron, więc jeżeli Julcia temu wszystkiemu podoła i utrzyma się przy Świdniku, to czyż niesłusznie mówię, że będzie najdzielniejszą kobietą, jaką znam.

a Opuszczono fragment, w którym A. Czechówna żali się na brak wiadomości od Promińskich, Hani Rydlówny, Heleny Rydlowej. Przykro jej, że obecnie nikt nie liczy się z jej zdaniem

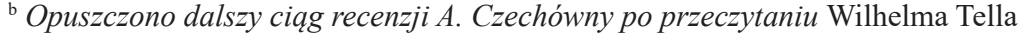


Do tego wszystkiego przybywa jeszcze zmartwienie i niepokój o Marysię. - Dziewczyna jest zdolna i nie ma żadnej obawy, aby nie zdała matury, ale jej pańskie nawyczki, i jej nieszanowanie rzeczy i nieporządek, może doprawdy przestraszać. [...] [a [s. 197] [...] Przy tem Julcię bardzo to martwi, że Marysia nie odczuwa zupełnie jej smutnego obecnie położenia i czy zboże gnije lub nie, to ją to nic nie obchodzi, i ciągle chciałaby się tylko bawić, ciągle urządzać jakieś wycieczki, to do Krynicy, to do Szczawnicy. [... $]^{\mathrm{b}}$

\section{[s. 198] [...] Poniedziałek, 9 września}

Do kłopotów Julcinych przybywa jeszcze i to, że ta dziewczyna, nie mając zdrowia, nic się nie szanuje, zaziębia się ciągle, co się i teraz stało, tak że jest bardzo zachrypnięta i kaszle ogromnie, a tu za kilka dni trzeba jechać do Krakowa. Do tego wszystkiego jest ona szalenie uparta, nie przyjmuje żadnej uwagi, // [s. 199] zaraz się obrusza, jednem słowem dziękuję Bogu, że nie będzie mieszkać u mnie. Ale gdzie ją Julcia umieści, jeszcze nie wiadomo. - Myślałyśmy o Promińskich, ale Brońcia wynajęła już pokój komu innemu i miejsca nie ma.

W tych dniach przeczytałam Makbeta w tłomaczeniu [!] Schillera. Tłomaczenie ładne, ale zdaje mi się, że Schiller odstąpił tu cokolwiek od oryginału, a w takim razie można by mu zrobić wielki zarzut, ale nie mając tutaj oryginału nie mogę osądzić, czy mam słuszność lub nie. $[\ldots]^{\mathrm{c}}$

[s. 200] [...] Muszę tu jeszcze zapisać, że Langowa bawi ciągle w Zakopanem, zaś jej córka Marynia, która skończyła szkołę w Snopkowie ${ }^{100}$, będzie nauczycielką w Podegrodziu, w szkole dla gospodyń wiejskich ${ }^{101}$. Będąc wczoraj w kościele w Podegrodziu, gdyż z powodu zepsucia drogi do Łukowicy ${ }^{102}$ dostać się nie można, poleciłam ją opiece kierowniczki tejże szkoły, która także była w kościele. //

\section{[s. 201] Czwartek, 12 września}

Z powodu zaziębienia Marysi wyjazd nasz wstrzymany do tygodnia. Najgorzej, że dotąd nie wiemy, gdzie w Krakowie ta stać będzie. Najprędzej u jakiejś pani Łukasiewiczowej, razem z Marsówną ${ }^{103}$, ale gdzie ona mieszka i co to za osoba, nie wiemy. Gdy wszyst-

\footnotetext{
a Opuszczono fragment mówiacy o złych nawykach Marysi Walterówny

b Opuszczono fragment, w którym A. Czechówna pisze o chętnie przyjmowanych przez Marysię Walterównę zalotach pana Chwalibogowskiego

c Opuszczono informację o innych przeczytanych w Świdniku powieściach, m.in. Na służbie Zofii Kowerskiej, Ewa zwycięska Piotra de Coulevain

${ }^{100}$ Prywatny Instytut Gospodarczego Kształcenia Kobiet w Snopkowie, szkoła założona w 1913 r. z fundacji księżnej Wandy Czartoryskiej, a prowadzona przez Janinę Karłowicz. Miała status szkoły wyższej.

${ }^{101}$ Podegrodzie, wieś w pow. nowosądeckim, położona ok. $10 \mathrm{~km}$ na południowy wschód od Świdnika. W 1913 r. powstała tam Szkoła Gospodyń Wiejskich. W Podegrodziu znajduje się kościół parafialny pw. św. Jakuba Apostoła.

${ }^{102}$ Łukowica, wieś położona ok. $3 \mathrm{~km}$ na północny zachód od Świdnika.

${ }^{103}$ Zofia Mars (Marsówna) (1896-1942), późniejsza artystka malarka. Po ukończeniu Prywatnego Gimnazjum Realnego Sióstr Urszulanek w Krakowie (matura 1917 r.) studiowała na UJ (1917-1919) i w krakowskiej Akademii Sztuk Pięknych. Należała do pierwszego rocznika kobiet, którym zezwolono na podjęcie studiów na tej uczelni (1919-1921, 1923-1926).
} 
ko to wyjaśni się dopiero w Krakowie, obecnie chciałabym jeszcze kilka słów poświęcić tutejszym sąsiedztwom. Otóż najbliższymi sąsiadami są Reklewscy z Rogów. Pożycie tych państwa jak dotąd nie było bardzo przykładne, gdyż ona sama, Weiglówna z domu, nie była jakoś zadowolona ani z męża ${ }^{104}$, ani ze swojego położenia, [s. 202] ale obecnie nastała między niemi jakaś lepsza harmonia i już dwa razy byli tutaj razem. Drugim sąsiedztwem to Brzezna, który to majątek dzierżawią od Stadnickiego ${ }^{105}$ państwo Skąpscy, ludzie bardzo zacni, żyjący ze sobą jak najlepiej i mają siedmioro dzieci. On jest zawołanym gospodarzem, więc jakoś wystarczają na edukację dzieci i właśnie dwóch synów odwieźli do Chyrowa ${ }^{106}$, a Reklewscy, którzy mają dwóch chłopczyków, jednego starszego. Julcia była tam już z Marysią, ale mnie nikt nie prosił, więc nie pojechałam. Coraz więcej widzę, że ze śmiercią Lucjana powinnam się już przyzwyczajać do roli staruszki, której towarzystwo jest dla wszystkich zbyteczne i wcale niepożądane. //

\section{[s. 203] Środa, 19 września}

Jutro wyjeżdżam ze Świdnika. Wyjeżdżamy końmi na Bilczyce i jedziemy razem z Kopaczyńskiemi, którzy wracają z Krynicy znacznie pokrzepieni i lepiej chodzący. [... ${ }^{\mathrm{a}}$

\section{[s. 204] Czwartek, 20 września}

Mam tu do zanotowania same złe wiadomości. Już byłam prawie zapakowana i miałyśmy jechać razem z Kopaczyńskiemi, gdy nadszedł list od Kloci. Pisze, żebyśmy wstrzymały nasz przyjazd, gdyż Konda jest prawie umierająca na zapalenie płuc. Biedna Klocia użyła z nią bardzo wiele biedy, gdyż w żaden sposób nie chciała iść do szpitala. Klocia musiała jej oddawać wszystkie posługi, podnosić na łóżku i dopiero dr Buzdygan i jakiś ksiądz Dominikanin nakłonili ją do wyniesienia się, ale gdy ten list Klocia pisała, była ona jeszcze w domu. Najgorzej, że nie mamy służącej, // [s. 205] wystawiam więc sobie, co tam biedna Klocia przechodzi i co mnie czeka za przyjazdem do Krakowa. - Tak wiernej służącej jak Konda pewnie już nie dostaniemy [...]

Z Kopaczyńskiemi było ułożone, że mamy wyjechać do Bilczyc w sobotę, zabawić tam przez niedzielę, a w poniedziałek do Krakowa. Tymczasem Marysia znów się rozchoro-

\footnotetext{
a Opuszczono informację o zachowaniu Marysi Walterówny, która kokietuje i porucznika Chwalibogowskiego, i młodego Krzyszkowskiego, dawnego ich sasiada. Byt to zapewne Bolesław Krzyszkowski, syn Zygmunta i Karoliny Krzyszkowskich, którzy w 1914 r. odsprzedali swe dobra w Świdniku Władysławowi Walterowi, mężowi Julii

${ }^{104}$ Janina z Weiglów, córka Artura, notariusza w Nowym Targu i Władysławy z Chwalibogowskich, żona Józefa Reklewskiego, syna Zofii i Romana.

${ }^{105}$ Brzezna, wieś położona ok. 9 km na wschód od Świdnika. Na przełomie XIX i XX w. stanowiła własność Stadnickich z Nawojowej. W 1914 r. właścicielem Brzezny był Adam Zbigniew hr. Stadnicki (1882-1982), ziemianin, leśnik, działacz polityczny, syn Edwarda Adama (1856-1885) i Heleny z Sapiehów (1857-1947). Jako trzyletnie dziecko stracił ojca, który uczynił go jedynym spadkobiercą swych majątków, m.in. Nawojowej i Brzeznej (Brzeźnej). Jan Skąpski (1873-1950), absolwent Szkoły Rolniczej w Czernichowie z żoną Zofią z Odrowąż Pieniążków (1881-1961) dzierżawili Brzeznę w latach 1908-1920.

${ }^{106}$ Zakład Naukowo-Wychowawczy Ojców Jezuitów w Chyrowie koło Przemyśla, szkoła o statusie gimnazjum, założona i prowadzona w latach 1883-1939. Uważana za jedną z najlepszych szkół w Polsce i w Europie.
} 
wała. Kaszle, ma gorączkę, jednem słowem nie wiem, czyli nasz wyjazd w sobotę będzie możliwy. Co do mnie, to wcale bym się nie gniewała, abym tu jeszcze kilka dni mogła pozostać, zwłaszcza // [s. 206] że i pogoda zrobiła się prześliczna, jakiej nie mieliśmy przez całe lato, ale ze względu na Marysię, która ma przecie rozpocząć naukę, i ze względu na Klocię, trzeba by nam już jechać koniecznie.

\section{Poniedziałek, 23 września}

Dopiero jutro mamy wyjechać ze Świdnika, ale nie powiem, żebym się na ten wyjazd cieszyła. W ogóle powiem, że wrzesień obudza we mnie takie wspomnienia, iż tylko boleść i tęsknotę mogą we mnie wywołać. Przecież to we wrześniu przyjeżdżał Lucjan zawsze do Krakowa i po przywitaniu pełnem zawsze serdeczności, zaczął mnie zwykle usilnie namawiać, abym chodziła na jego wykłady. Kiedy zaś sobie przypomnę, jak urocze // [s. 207] i pełne czaru słowa płynęły zwykle z jego katedry, a były zwykle skierowane tylko do mnie, jak to widziałam, i jak mi to sam później mówił. Kiedy sobie dalej przypomnę, jak po wykładzie on usilnie szukał mojego towarzystwa i gonił za mną już po schodach, ażebym mu tylko powiedziała, czy się zgadzam na jego poglądy i czy one trafiają do mojego przekonania, toteż kiedy sobie dzisiaj pomyślę, że to już wszystko stracone, to taki ból i tęsknotę czuję, że łzy gwałtem cisną mi się do oczów. Kiedy zaś do tego wszystkiego pomyślę, że kiedy dawniej wracałam, witała mnie Konda, która wszystko w domu przyrządziła, a teraz zastanę dom bez sługi i kto wie // [s. 208] z jakiemi stratami, to i to również nie przyczynia się do przyjemnego do Krakowa powrotu. Na jedno tylko, a podobno najważniejsze cieszę się, to jest na kościół i możność przystępowania do Św. Sakramentów. Bo gdy z powodu zepsucia drogi do Łukowicy jeździmy tylko do dalszego Podegrodzia na sumę w niedzielę, nie byłam już więcej jak 6 tygodni do spowiedzi, nie przyjmowałam Jezusa, więc mam nadzieję, że gdy w Krakowie przyjdzie mi to łatwo, to z pewnością i wszystkie moje tęsknoty zostaną zażegnane i ukojone. //

\section{[s. 209] Czwartek, 26 września}

Zamiast w Krakowie piszę jeszcze ten pamiętnik w Świdniku. Marysia nie może jakoś przyjść do siebie, do czego przyczynia się zapewne to, że się po influenzy nie szanuje, zaziębia się, a wskutek tego i kaszel nie ustaje. Jest to bardzo zjadliwa influenza, zwana chorobą hiszpańską, a do tego panuje wszędzie epidemicznie. I tu większa część służby leży, a gdy i furman, który miał z nami jechać do Bilczyc, także się rozchorował, więc z konieczności musimy tu jeszcze zostać, jakkolwiek czas na Marysię wielki. // [...] $]^{\mathrm{a}}$

\section{[s. 211] [Piątek], 4 października}

Po przyjemnych chwilach w Świdniku nastąpiły bardzo smutne. Śmiertelność na tę hiszpańską chorobę wzrasta. Połowa służby leży, a nawet dwoje już umarło. Co się dzieje w Krakowie, wiemy tylko z gazet, że z powodu tej choroby i szkoły mają być zamknięte. Klocia nic nie pisze, więc pewnie i ona chora. Do tego wszystkiego nastąpiła taka słota i zimno, że w moim pokoju, który jest tylko dobrym na lato, gdyż wszędzie wieje, a jedna

\footnotetext{
a Opuszczono fragment, w którym A. Czechówna napisała, że w Krakowie Klotylda Kowalska przyjęła nowa stużąca oraz o zaniepokojeniu pamiętnikarki pogarszającym się stanem swego zdrowia
} 
ściana jest tylko deskami zaszalowana, można ze zimna uśkwirkną́c ${ }^{107}$, toteż i na // [s. 212] mój romantyzm [!] jest coraz gorzej i co lato naprawiło, to taki czas może zepsuć.

Bawi tu obecnie siostra starej Walterowej, Jaroszowa ze Lwowa, a że tam, jak sama opowiada, głodno i chłodno, więc też tutaj nie żałuje Julci i jada za dwie. Przyjechał tu także Józef Walter z Krościenka, brat Władzia ${ }^{108}$, ale ten już jutro wraca do domu. Kiedy ja powrócę do Krakowa, jeszcze nie wiem, ale już jest zdecydowane, że powrócę koleją, gdyż Marysia po swojej chorobie nie może jechać na koźle ani na przodniej [!] ławeczce. //

\section{[s. 213] Świdnik, poniedziałek, 7 października}

Dochodzę do przekonania, że Julcia będzie miała jeszcze niemało do przeniesienia z powodu Marysi. Obecnie jej zdrowie bardzo delikatne, a przy tem jej pańskie nawyczki, nieszanowanie rzeczy i jej zamiłowanie do strojów napełnia ją już wielką obawą, ale obecnie powstaje nowa dla niej obawa.

O ile wiem od samej Marysi, to ten ułan Chwalibogowski jest nią zajęty i Marysia także nie jest względem niego obojętna. Julcia ten ich stosunek bierze ze strony żartobliwej, niewinnego flirtu salonowego. [... ${ }^{\mathrm{a}}$ [s. 214] [...] Dla mnie osobiście jest Chwalibogowski bardzo sympatycznym i okazującym mi także wiele uprzejmości, ale jako z konkurenta do Marysi Jula nie będzie, bo nie może być, zadowolona. Jedna rzecz także niepokoi mnie // [s. 215] w tej całej sprawie. Wobec ubóstwa sąsiedztw w tej okolicy Rogi jako najbliższe stanowią prawie że jedyny żywioł towarzyski dla Świdnika. Ponieważ zaś Chwalibogowski jest ciotecznym bratem Reklewskiej, gdyby więc Julcia odmówiła mu Marysi, stosunki te bardzo by się oziębiły, gdyż uważam że Reklewscy bardzo sobie tego związku życzą. //

\section{[s. 216] Kraków, 18 października}

Nie wiem doprawdy, od czego mam zacząć to sprawozdanie. Myślałam, że wspomnę tylko o moim powrocie i o moich domowych sprawach, a temczasem wszystko to jest nic nie znaczącem, wobec politycznych wiadomości, jakie przynoszą gazety. Pogrom Niemców zupełny i Rada Regencyjna w Warszawie, idąc zapewnie za wskazówkami Francji, Anglii, a przede wszystkiem Wilsona, prezydenta Stanów Amerykańskich, ogłasza Polskę niepodległą w dawnych granicach, a tem samem z Poznańskiem, Galicją, Księstwem Cieszyńskiem i z Gdańskiem jako portem. // [s. 217] - Niemcy są wściekli, ale zdaje się, że tym razem będą musieli ustąpić jako pobici. - Naturalnie, że radość wszędzie panuje wielka, ale zanim się to wszystko stanie, upłynie jeszcze wiele wody, a podobno i krwi, gdyż ani można przypuścić, aby wszystko gładko poszło. Ja żałuję tylko, że Lucjan nie dożył tej chwili, która spełnia wszystkie jego marzenia, spodziewać się jednak można, że człowiek tak pobożny i tak umierający jak on jest przy łasce Boskiej, a tem samem wie, co się tu dzieje. //

\section{[s. 218] Wtorek, 22 października}

Co się tyczy moich spraw rodzinnych i domowych, to najprzód muszę tu zapisać, że o ile może mi jeszcze być dobrze, to jest mi dobrze z Klocią jako z osobą tak dobrą, zacną

\footnotetext{
${ }^{a}$ Opuszczono rozważania A. Czechówny dotyczace niekoniecznie niewinnego flirtu między Marysia Walterówną a Chwalibogowskim i ewentualnych jego następstw

${ }^{107}$ Prawidłowa forma: uświerknąć - pot. przemarznąć.

108 Józef Walter (1870-1947), magister farmacji (1892), właściciel apteki „Pod Trzema Koronami” w Krościenku.
} 
i pobożną. Sługę mamy także jakąś dobrą i nabożną, a lubo gotować nie bardzo umie i wskutek tego obiady po świdnickim kucharzu kłują czasem w zęby, ale do wszystkiego można się przyzwyczaić. Raz na tydzień będę bywała u Promińskiej na obiedzie, gdyż ta zostaje z dziećmi w Krakowie i tylko on sam pojechał do Lwowa. - Byłam także u Rydlowej, ale znalazłam, że jest zmieniona, mizerna i wcale nie widać // [s. 219] pokrzepienia na wiejskiem powietrzu. Także i Langowa, która wróciła na kilka dni ze Zakopanego, musi tam znów powrócić na całą zimę, gdyż jak uważam, nie jest z nią dobrze. Mizerna i kaszląca, widocznie więc gruźlica robi u niej postępy. - Oby Rydlowa nie musiała i ją jeszcze przeżyć.

U nas w domu zastałam wszystko w porządku, ale Henryk, wyjechawszy ostatniemi czasy na wieś, został doszczętnie okradziony z bielizny i garderoby, w które był bardzo bogaty, więc strata znaczna. //

\section{[s. 220] Niedziela, 27 października}

Nie wiem, jak ateusze tłomaczą sobie obecne wypadki, ale ja widzę w nich tak jaśne [!] i wyraźne działanie Opatrzności, iż cała dzisiejsza polityka wydaje mi się być tylko Jej dziełem. Gnębieni i prześladowani blisko przez lat 150, nagle mamy mieć zwrócone wszystkie nasze ziemie i Polska w cudowny sposób zmartwychwstaje i ożywia się. Mówią, że to dzieło Ameryki, a głównie jej prezydenta Wilsona, ale kto tam posłał Paderewskiego, owego sławnego fortepianistę ${ }^{109}$, który zaniedbawszy muzykę, poświęcił // [s. 221] się głównie polityce i zaprzyjaźniwszy się z Wilsonem, zwrócił jego uwagę na nasze smutne położenie i na nasze krzywdy. Czyż w tem wszystkiem nie widać palca Bożego i Jego działalności? Czyż nie widać tutaj, że Matka Najświętsza, zarówno w Częstochowie, jak i w Ostrej Bramie wysłuchała naszych próśb, naszych błagań i jako Królowa Polska zlitowała się nad nami.

Mówiła mi służąca, że u Dominikanów było uroczyste nabożeństwo przed cudownym obrazem, i że księża wystąpili w zupełnie nowych ornatach z Orłami polskiemi. Ja tego wszystkiego nie widzę, // [s. 222] gdyż z powodu bólu nogi mogę tylko bywać w najbliższych kościołach. Nie mogę także już bywać na jakichkolwiek posiedzeniach i zgromadzeniach, ale wyręcza mnie Klocia, której dałam polecenie, aby mnie zapisała do wszystkich tworzących się obecnie patriotycznych związków, gdyż nie mogąc moją pracą, przynajmniej moim groszem pragnę być użyteczną. //

${ }^{109}$ Ignacy Jan Paderewski (1860-1941), pianista, kompozytor, działacz niepodległościowy. Po wybuchu I wojny światowej prowadził szeroką działalność dyplomatyczną na rzecz pomocy Polakom i realizacji idei odrodzenia państwa polskiego. W styczniu 1915 r. wraz z Henrykiem Sienkiewiczem (1846-1916) w neutralnej Szwajcarii założył Comité Général de Suisse pour les Victimes de la Guerre en Pologne (Szwajcarski Komitet Generalny Pomocy Ofiarom Wojny w Polsce). Jego liczne oddziały powstały też w Paryżu, Londynie, Nowym Jorku. W 1915 r. wyjechał do USA, gdzie do maja 1917 r. wiele koncertował, przed każdym koncertem apelując o pomoc dla Polski. Z początkiem 1916 r. poznał osobiście najbliższego współpracownika prezydenta Wilsona Edwarda House'a, za pośrednictwem którego w styczniu 1917 r. przekazał mu memoriał na temat Polski. Kilkakrotnie spotykał się też osobiście z prezydentem USA. W dniu 25 grudnia 1918 r. Paderewski przybył do Gdańska, skąd udał się do Poznania. 


\section{[s. 223] Środa, 30 października}

Wypadki postępują po sobie z błyskawiczną szybkością, tak że nie można się w nich nawet zorientować. - To jest tylko rzeczą pewną, że zarówno Prusy, jak i Austria są zupełnie pokonane - bezsilne i muszą, rade nie rade przyjmować warunki Wilsona, a te warunki są i ciężkie, i upokarzające.

Wilson z Wilhelmem, cesarzem pruskim, nie chce nawet konferować i to nie tylko z nim, ale ani z jego synem ${ }^{110}$, jak chciał Wilhelm, ani z wnukiem, jednem słowem Hohenzollerni muszą pójść w odstawkę, a Niemcy // [s. 224] muszą sobie wybrać innego przedstawiciela. - Wywołało to dowcip antyniemiecki, że te miały dwunastu apostołów, a wszystkich na $\mathrm{H}$, toteż mówią o nich Waren hoch - sind hin ${ }^{111}$. Holweg - Hötzendorf Helferich - Hertling - Hoffmann - Hohenlohe - Hindenburg - Hussarek - Hinze - Huyn Habsburg - Hohenzoller ${ }^{12}$.

Ponieważ przy tem ukształtowaniu się polityki Czesi będą mieli osobne królestwo ${ }^{113}$, czytamy w gazetach, że w Pradze są niebywałe demonstracje i zapał nie do opisania. Nie można tego powiedzieć o Krakowie, gdyż może pod wpływem panującego głodu // w towarzystwie morderczej hiszpanki, nikt się jakoś nie cieszy i usposobienie jest więcej poważne jak radosnea .

a A. Czechówna w 1919 r. tak skomentowała sytuację: Okazało się, że jeszcze przy końcu r. [1]919, gdy czytam ten pamiętnik, Niemcy nie są wcale tak pokornymi, jakby się zdawało i złączywszy się $\mathrm{z}$ bolszewikami, socjalistami, a nawet z Czechami intrygują i kopią pod nami doły na każdym punkcie, ale może też Bóg da, że nie potrafią nas zwyciężyć

${ }^{110}$ Wilhelm II Hohenzollern (1859-1941), od 1888 r. cesarz Niemiec i król Prus, zdecydowany zwolennik wojny. 9 listopada 1918 r. zmuszony był zrezygnować z tronu Rzeszy i Prus, co potwierdził dokumentem z 28 listopada 1918 r. Jego syn Wilhelm von Preussen (1882-1951), następca tronu Prus i Niemiec, uczestniczył w wojnie jako oficer. Po abdykacji ojca zrzekł się praw do tronu. Holandia udzieliła ojcu i synowi azylu.

${ }^{111}$ Waren hoch - sind hin (niem.) - byli wysoko teraz upadli.

112 Theobald von Bethmann-Hollweg (1856-1921), kanclerz Cesarstwa Niemieckiego i premier Prus w latach 1909-1917; Franz Conrad von Hötzendorf (1852-1925), szef sztabu generalnego armii austro-węgierskiej (1906-1917); Karl Helfferich (1872-1921), sekretarz skarbu odpowiedzialny za pozyskiwanie funduszy na cele wojenne Rzeszy poprzez pożyczki (zamiast podatków); Georg von Hertling (1843-1919), premier Bawarii (1912-1917), kanclerz Cesarstwa Niemieckiego i premier Prus (1917-1918); Max Hoffmann (1869-1927), niemiecki generał, od 1916 r. szef sztabu na froncie wschodnim; Gottfried książę zu Hohenlohe-Schillingsfürst (1867-1932), generał, ambasador Austro-Węgier w Berlinie (1914-1918); Paul Hindenburg von Beneckendorff (1847-1934), feldmarszałek niemiecki, od 1 listopada 1914 r. wódz wojsk niemieckich na froncie wschodnim, a od lipca $1916 \mathrm{r}$. również wojsk austriackich; Maksymilian Hussarek von Heinlein (1865-1935), minister wyznania i oświaty Austro-Węgier (1911-1917), premier (lipiec-październik 1918); Paul von Hintze (18641941), admirał, podczas I wojny światowej poseł w Chinach (1914-1915) i w Norwegii (1915-1918), minister spraw zagranicznych (lipiec-październik 1918); Karl Georg Huyn (1857-1938), austriacki generał, ostatni generał-gubernator Galicji (marzec 1917 r. - listopad 1918 r.).

$113 \mathrm{~W}$ dniu 28 października, po serii manifestacji niepodległościowych i strajku generalnym, Czechosłowacki Komitet Narodowy ogłosił w Pradze powstanie suwerennego państwa czechosłowackiego. 


\section{[s. 226] Piątek, 1 listopada}

Wypadki postępują z taką szybkością, iż trudno nadążyć w zapisywaniu tychże. Wczoraj np. był bardzo ważny i prawdziwie historyczny dzień dla Krakowa. - Bez żadnej rewolucji i zamięszania [!] pozrzucano Orły austriackie, a umieszczono polskie. Z odwachu ustąpiła dobrowolnie załoga austriacka, a objęło takowy wojsko polskie, nad którym w Krakowie objął komendę brygadier Roja114.

Jak dotąd wszystko odbywa się // [s. 227] bardzo spokojnie i porządnie. Ja niewiele widzę, gdyż z powodu bólu nogi bywam tylko w najbliższych kościołach i nawet do Rynku nie dochodzę, ale Klocia bywa wszędzie, więc mi opowiada. U Promińskiej bywam raz w tygodniu na obiedzie, naturalnie tramwajem. Odwiedziłam także i Henryka, który jest bardzo zmartwiony, gdyż jak dotąd z jego kosztownych rzeczy nic się nie znalazło. Lubo względem mnie jest on dosyć serdecznym, do mnie nie przychodzi wcale, nie chcąc się widzieć z Klocią, na którą ciągle się gniewa [... $]^{\mathrm{a}}$.

\section{[s. 228] [...] Sobota, 2 listopada}

Wśród tych dziwnych i niezapomnianych chwil, jakie obecnie przeżywamy, przypadła rocznica Matejkowska, bo 25-lecie od jego śmierci ${ }^{115}$. Rocznicę tę uczczono nabożeństwem u Panny Marii, a zarazem pięknemi przemowami w Muzeum Narodowem w Sukiennicach, obok jego obrazu Hołdu pruskiego ${ }^{116}$.

Najpiękniejsze przemówienie było Włodzimierza Tetmajera ${ }^{117}$, który bardzo słusznie podniósł, // [s. 229] iż często ludzie gienialni, czy to na polu literatury, czy poezji lub sztuki, są zarazem bardzo przewidującymi politykami, i takim był Matejko, wskazując swojemu narodowi najlepszą i najzbawienniejszą drogę.

Tadzio Kremer zachęca mnie znów, ażebym poszła na Wyzwolenie Wyspiańskiego do teatru. Dawano tę sztukę również na uczczenie 25-lecia istnienia teatru im. Słowackiego. Przedstawienie miało być świetne i zastosowane do obecnej chwili, gdy jednak nie czuję się zdrową i noga mnie boli, więc nie byłam. //

\footnotetext{
a Opuszczono dalsze rozważania A. Czechówny odnośnie do konfliktu między rodzeństwem Klotylda i Henrykiem Kowalskimi

${ }^{114}$ Bolesław Jerzy Roja (1876-1940) - zob. przyp. 19. 31 października przejął z rąk Austriaków Komendę Wojskową miasta i jeszcze tego samego dnia ogłosił rozkaz mobilizacyjny Komendy wojsk polskich w Krakowie.

${ }^{115}$ J. Matejko zmarł 1 listopada $1893 \mathrm{r}$.

${ }^{116}$ Uroczystości ku czci Matejki zaplanowane na 31 października wprawdzie się odbyły, ale „wypadki, które dzisiaj przeżywało miasto, osłabiły nieco zainteresowanie tym obchodem”. Najpierw bp Anatol Nowak odprawił w kościele Mariackim nabożeństwo, następnie Mistrzowi oddano hołd w Sukiennicach. Przemawiali tam: wiceprezydent Karol Rolle (1871-1954), w imieniu Związku Artystów poseł Włodzimierz Tetmajer i w imieniu Akademii Umiejętności jej prezes prof. Kazimierz Morawski (1852-1925), zob. „Czas” nr 486 z 31 października 1918 r., s. 2.

117 Włodzimierz Tetmajer (1861-1923), malarz i grafik, działacz ludowy i niepodległościowy. Jego żoną była Anna z Mikołajczyków (1874-1954), siostra Jadwigi Rydlowej. Mieszkali w Bronowicach, najpierw w drewnianym domu wybudowanym na polu Jacka Mikołajczyka (obecna Rydlówka), następnie w starym pofranciszkańskim dworku (obecna Tetmajerówka).
} 


\section{BIBLIOGRAFIA}

\section{Źródła rękopiśmienne i drukowane}

Archiwum Narodowe w Krakowie

Spuścizna Aleksandry Czechówny, sygn. 29/1582/35 (dawna sygn. IT 428/35), sygn. 29/1582/37 (dawna sygn. IT 428/37), sygn. 29/1582/42 (dawna sygn. IT 428/42). Zbiór afiszy i plakatów, sygn. 29/665/1195, 29/665/1475, 29/665/1476, 29/665/1497.

\section{Prasa}

„Czas” 1918, nr 8, 195, 196, 306, 308, 310, 312, 314, 316, 318, 486.

„Nowa Reforma” 1918, nr 162, 164.

\section{Opracowania}

Bąkowski Klemens: Kronika Krakowa z lat 1918-1923. Kraków: Gebethner i Wolff, 1925. Chmiel Adam: Oswobodzenie Krakowa 31 października 1918 roku. Kraków: Nakładem „Związku Uczestników Oswobodzenia Krakowa”, 1929.

Homola-Skąpska Irena: Życie codzienne w czasie I wojny światowej w dziennikach krakowskiego adwokata Klemensa Bąkowskiego. ,Rocznik Biblioteki Naukowej PAU i PAN w Krakowie" 2005, R. 50, s. 330.

Lesiak-Przybył Bożena: Wielka wojna w „Dzienniku” Aleksandry Czechówny (część I: 2 lipca 1914 r. - 26 grudnia 1914 r.). „Krakowski Rocznik Archiwalny” 2014, t. 20, s. 111-132.

Lesiak-Przybył Bożena: Wielka wojna w „Dzienniku” Aleksandry Czechówny (część II: 2 stycznia - 26 grudnia 1915 r.). „Krakowski Rocznik Archiwalny” 2015, t. 21, s. $133-163$.

Lesiak-Przybył Bożena: Wielka wojna w „Dzienniku” Aleksandry Czechówny (część III: 2 stycznia - 27 grudnia 1916 r.). „Krakowski Rocznik Archiwalny” 2016, t. 22, s. $139-170$.

Lesiak-Przybył Bożena: Wielka wojna w „Dzienniku” Aleksandry Czechówny (część IV: 1 stycznia - 29 grudnia 1917 r.). „Krakowski Rocznik Archiwalny” 2017, t. 23, s. 181-215.

Rydel Lucjan: Poezje. Wydanie trzecie znacznie pomnożone. Kraków: Skład Główny w Księgarni D. E. Friedleina Nakład Leona Idzikowskiego w Kijowie, 1909.

Samozwaniec Magdalena: Maria i Magdalena. Warszawa: Świat Książki, 2010.

Zgórniak Marian: 1914-1918. Studia i szkice z dziejów I wojny światowej. Kraków: Wydawnictwo Literackie, 1987.

\section{Wydawnictwa elektroniczne}

Cyfrowa Biblioteka Polskiej Piosenki, http://www.bibliotekapiosenki.pl/utwory/Boze_ Ojcze_Twoje_dzieci (odczyt: 14.03.2018). 


\section{PODSUMOWANIE \\ Wielka wojna w „Dzienniku” Aleksandry Czechówny \\ (część V: 5 stycznia - 2 listopada 1918 r.)}

Aleksandra Czechówna (1839-1923) była córką Tomasza Czecha i Aleksandry z Zielińskich. Jej „Dziennik z całego życia...”, pisany przez blisko 70 lat (1856-1923), przechowywany jest w Archiwum Narodowym w Krakowie pod sygn. 29/1582/1-29/1582/44 (sygn. dawne IT 428/1-428/44). Stanowi znakomite źródło obrazujące życie kulturalne, towarzyskie i obyczajowe miasta Krakowa w drugiej połowie XIX w. oraz w pierwszym dwudziestoleciu XX w.

Zamieszczony tu tekst pochodzi z tomu 42 „Dziennika”, sygn. 29/1582/42 (dawna sygn. IT 428/42). Stanowi kontynuację zapisów dotyczących pierwszych czterech lat I wojny światowej i opisuje piąty rok toczących się walk (zob. „Krakowski Rocznik Archiwalny" 2014 , t. 20 , s. $111-132 ; 2015$, t. 21 , s. $133-163 ; 2016$, t. 22, s. $139-170 ; 2017$, t. 23 , s. 181-215).

Prezentowany wybór spisany został przez wnikliwą obserwatorkę tak ważnych dla Polaków wydarzeń. Autorka korzystała głównie z doniesień prasowych i urzędowych obwieszczeń, ale też posiłkowała się relacjami osób. Dlatego opis sytuacji niewątpliwie nie jest pełny, zwłaszcza w odniesieniu do sfery polityki. Dostarcza jednak szeregu informacji o wydarzeniach rozgrywających się na froncie wschodnim oraz w Krakowie. Daje obraz niezwykle już trudnego, pełnego trosk, wyrzeczeń i niedostatku życia codziennego mieszkańców miasta w kolejnym roku toczącej się wojny. Przynosi też opis stanu uczuć Polaków, ich nieustannej niepewności, ale i wielkich oczekiwań związanych z przywróceniem państwowości polskiej. A kiedy marzenia Polaków wreszcie się urzeczywistniły i Polska odzyskała niepodległość, to obok ogromnej radości A. Czechównę nadal niepokoiły zarówno sytuacja międzynarodowa, jak i wewnętrzne konflikty.

\section{SUMMARY \\ The Great War in the "Journal" of Aleksandra Czechówna (Part V: 5 January - 2 November 1918)}

Aleksandra Czechówna (1839-1923) was the daughter of Tomasz Czech and Aleksandra, née Zielińska. Her "Journal from the whole life...", written for almost 70 years (18561923), is stored in the National Archives in Krakow, ref. no. 29/1582/1-29/1582/44 (former ref. no. IT 428/1-428/44). It represents a great source that depicts the cultural, social and daily life of Krakow in the second half of the $19^{\text {th }}$ century, and the first two decades of the $20^{\text {th }}$ century.

The text placed here comes from volume 42 of the "Journal", ref. no. 29/1582/42 (former ref. no. IT 428/42). It represents a continuation of the entries concerning the first four years of World War I and describes the fifth year of the ongoing fight (see "Krakowski Rocznik Archiwalny” 2014, vol. 20, pp. 111-132; 2015, vol. 21, pp. 133-163; 2016, vol. 22, pp. 139-170). 
The presented text was written by a perceptive observer of events of great importance for Poles. The author mainly used press reports and clerical announcements, but also made use of personal accounts. The description of the situation is, therefore, incomplete, especially with regard to politics. It does, however, provide a wide range of information about the events taking place on the eastern front as well as in Krakow. It paints a picture of the difficult daily life, full of worries, sacrifices and shortages, of the residents of the city in the next year of the ongoing war. It also provides a description of the feeling of Poles, their constant uncertainty, but also the great expectations connected with recreating a Polish state. When the dreams of Poles finally became a reality and Poland regained independence, beside the great joy, A. Czechówna was still worried by the international situation and internal conflicts.

SŁOWA KLUCZOWE: I wojna światowa, Kraków, dziennik, codzienność, Aleksandra Czechówna, 1918

KEY WORDS: World War I, Krakow, journal, daily life, Aleksandra Czechówna, 1918 